\title{
Rolands Neilands
}

\section{HIPOTĒKAS INSTITŪTS UN TĀ PILNVEIDOŠANAS IESPĒJAS LATVIJAS TIESĪBĀS}

Promocijas darba kopsavilkums tiesību doktora zinātniskā grāda iegūšanai

Apakšnozare - civiltiesības 


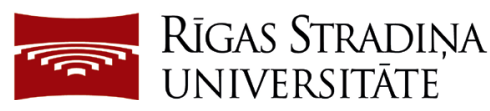

\author{
Rolands Neilands
}

\title{
HIPOTĒKAS INSTITŪTS UN TĀ \\ PILNVEIDOŠANAS IESPĒJAS \\ LATVIJAS TIESİBĀS
}

\author{
Promocijas darba kopsavilkums \\ tiesību doktora zinātniskā grāda iegūšanai
}

Apakšnozare - civiltiesības

Rīga, 2017 
Promocijas darbs izstrādāts Rīgas Stradiṇa universitātē.

Darba zinātniskais vadītājs:

Dr. iur. asociētais profesors Jānis Grasis,

Rīgas Stradiņa universitāte, Latvija

Oficiālie recenzenti:

Dr. iur. docente Inga Kudeikina,

Rīgas Stradiņa universitāte, Latvija

Dr. iur. profesore Ingrīda Veikša,

Biznesa augstskola "Turība", Latvija

Dr. habil. iur., PhD asociētais profesors István Sándor,

Eötvös Loránd Universitāte, Ungārija

Promocijas darba aizstāvēšana notiks 2017. gada 27. jūnijā plkst. 14.00 Rīgas Stradiṇa universitātes Juridiskās zinātnes promocijas padomes atklātā sēdē Rīgā, Dzirciema ielā 16, Hipokrāta auditorijā.

Ar promocijas darbu var iepazīties RSU bibliotēkā un RSU tīmekḷa vietnē: www.rsu.lv.

Promocijas padomes sekretāre:

Dr. iur. profesore Sandra Kaija 


\section{SATURS}

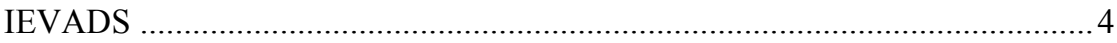

1. HIPOTĒKAS INSTITŪTA VĒSTURISKĀ ATTĪSTĪBA UN

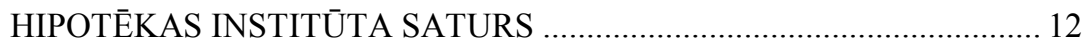

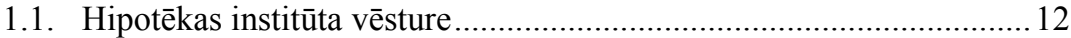

1.2. Hipotēkas vieta ķīlu sistēmā un hipotēkas sekas ................................15

2. HIPOTĒKAS VISPĀRĒJIE PROBLĒMU JAUTĀJUMI UN TO

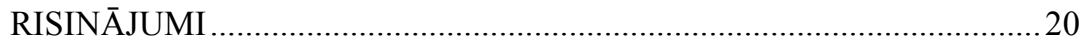

2.1. Fiktīvie īres līgumi un to mērkis........................................................20

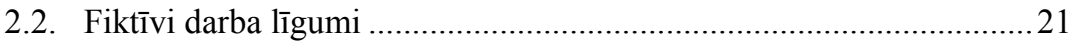

2.3. Hipotēkas noilguma problemātika ....................................................2 23

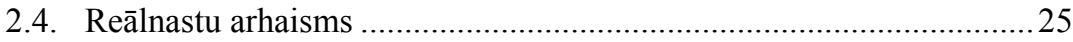

2.5. Bezregresa kredītu tiesiskā regulējuma problēmas .............................29

3. TREŠO PERSONU HIPOTĒKU PROBLĒMU JAUTĀJUMI UN TO

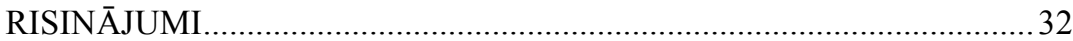

3.1. Hipotēkas akcesoritātes problemātika ............................................... 32

3.1. Par trešās personas saistībām nodrošinātā kreditora prasījuma

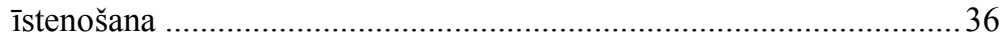

3.2. Ieḳīlātāja tiesības iepazîties ar informāciju par parāda apmēru ...........38

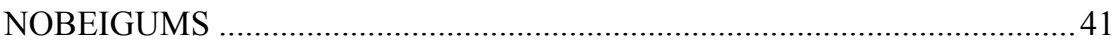

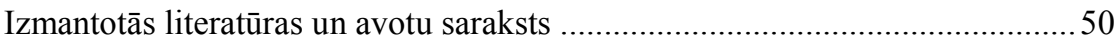




\section{IEVADS}

Pēdējā finanšu krīze (2008.-2013. gads) parādīja, ka finanšu stabilitātei ir ļoti liela nozīme finanšu sistēmas un valsts tautsaimniecības stabilitātes nodrošināšanā, kurā nozīmīgākā loma ir tieši kredītiestāžu finanšu stabilitātei. Kredītiestāžu darījumu pamatu pamats ir noguldījumu pieņemšana ar zemākām procentu likmēm un kredītu izsniegšana ar augstākām procentu likmēm, nodrošinot sev pel̦̦u no starpības. Tieši šie divi finanšu pakalpojumi noguldījumi un kredīiti ir nozīmīgākie kredītiestāžu darījumi, no kuriem ir atkarīga ne tikai kredītiestāžu pel̦na, bet arī kredītiestāžu pastāvēšana. Turklāt noguldītāju noguldījumu drošîba ir tieši atkarīga no kredītu drošības, tas ir, no tā, kā kredīti tiks atmaksāti - vai tie tiks atmaksāti laikā, vai tie tiks laicīgi uzraudzīti, iestājoties atmaksas kavējumiem, kā arī vai tie tiks piedzīti, ja aizṇēmēji neatmaksās kredītus.

Kā līdzeklis efektīvai piedziņai kalpo kredīta nodrošinājums - ķ̄ila vai galvojums. Hipotēka uz nekustamo īpašumu ir visplašāk izmantotais nodrošinājuma veids un tādēl hipotēkai ir būtiska loma kreditēšanas un visas tautsaimniecības attīstībā, kā arī finanšu stabilitātē.

Tēmas aktualitātes pamatā ir šādi aspekti:

1. Hipotēka ir būtiskākais ķīlu veids tautsaimniecībā. Pastāvot stabilam hipotēkas institūtam, var pastāvēt stabila un ilgtspējīga kreditēšana.

2. Lai gan kopumā hipotēkas institūts Latvijas tiesībās ir stabils un kalpo savam mērķim, pastāv daudzas hipotēkas institūtu skarošā tiesiskā regulējuma nepilnības, ko ir iespējams novērst ar normatīvo aktu grozījumiem.

3. Hipotēkas institūta stiprināšana dotu nozīmīgu pienesumu ne tikai kreditēšanas attīstībai un ilgtspējībai, bet arī investīciju vides uzlabošanai. Kā norāda Latvijas Bankas ekonomisti, lai novērstu vājas kreditēšanas ieilgšanu, nepieciešami plašāki ekonomiskās politikas pasākumi, kas nodrošinātu pamatu kreditēšanas ilgtspējīgai attīstībai un uzlabotu konfidenci. Cita starpā, ir svarīgi 
veidot investīcijām pievilcīgu vidi, uzlabot tiesu darbību un investoru tiesību aizsardzību. ${ }^{1}$

Pētījuma zinātnisko novitāti veido kompleksa hipotēkas institūta un hipotēkas īstenošanas problemātikas izpēte gan attiecībā uz piedziņas vēršanas uz nekustamajiem īpašumiem procesiem (civilprocesuālajā kārtībā), gan attiecībā uz kreditoru prasījumu apmierināšanu maksātnespējas procesos.

Promocijas darbs ir pabeigts zinātnisks pētījums. Autors izpētes procesā secīgi aplūko hipotēkas institūta izveidošanās un recepcijas vēsturi, hipotēkas institūta saturu un tā ietekmi uz hipotēkas realizēšanu, kā arī praksē pastāvošās problēmas. Pētījumam pievienoto vērtību pieškir autora praktiskā juridiskā darba pieredze banku nozarē vairāk kā 12 gadu garumā, kā arī vairāku gadu pieredze kā juristam kapitālsabiedrībās, kas izmanto banku pakalpojumus.

Promocijas darbā autors pēta, analizē, kā arī izvirza savus priekšlikumus normatīvo aktu grozījumiem tādu hipotēkas problēmu jautājumu risināšanai, kas līdz šim nav atrisināti, proti: 1) fiktīvu darba līgumu, kuru mērḳis ir apiet hipotēkas kreditoru, problēmas risinājumu; 2) kreditoru prasījumu noilgumu problēmas risinājumu; 3) reālnastu arhaisma problēmas risinājumu; 4) bezregresa kredītu obligātas piedāvāšanas potenciālajiem kredītṇēmējiem (patērētājiem) problēmas risinājumu; 5) trešo personu hipotēkas akcesoritātes problēmas risinājumu; 6) par trešās personas saistībām nodrošinātā kreditora prasījuma īstenošanas maksātnespējas procesos problēmas risinājumu; 7) ieķīlātāja tiesību neesamības iepazīties ar informāciju par parādnieka parādu problēmas risinājumu.

Pētījums ir nozīmīgs civiltiesību zinātnes attīstībai. Lielākajai daḷai no apskatītajiem problēmu jautājumiem autora piedāvātais risinājums ir inovatīvs.

\footnotetext{
${ }^{1}$ Finanšu Stabilitātes Pārskats 2016. Latvijas Banka. Iegūts no: https://www.makroekonomika.lv/sites/default/files/fsp_2016_1.pdf [sk. 07.11.2016.].

${ }^{2}$ Noteikt, ka nodrošinātā kreditora statuss attiecināms ne tikai uz maksātnespējīgā https://www.makroekonomika.lv/sites/default/files/fsp_2016_1.pdf [sk. 07.11.2016.].
} 
Turklāt darbs ir ne tikai viens no jaunākajiem pētījumiem lietu tiesību nozarē, bet vien̄̄gais zinātniskais pētījums mūsdienās, kurā padziḷināti un kompleksi ir pievērsta uzmanība hipotēkas institūtam un tā problemātikai.

Promocijas darba zinātniski praktiskā vērtība ir iespēja to izmanot kā izziņas avotu par hipotēkas institūtu un tā problemātiku praktizējošiem juristiem - tiesnešiem, zvērinātiem advokātiem, zvērinātiem tiesu izpildītājiem, maksātnespējas procesu administratoriem, kredītiestāžu juristiem, komersantu u.c. juristiem. Pētījums ir izmantojams arī tiesību zinātņu studentu teorētiskajā apmācībā, jo īpaši studiju priekšmetos Lietu tiesības, Maksātnespējas tiesības un Civilprocess. Pētījuma galvenā praktiskā nozīme ir likumdošanas jomā izmantojot pētījumu kā pamatu normatīvo aktu grozījumiem, lai stiprinātu hipotēkas institūtu.

Pētījuma mērḳis ir sagatavot zinātnisku pamatojumu hipotēkas institūta stiprināšanai un problēmu jautājumu novēršanai normatīvo aktu grozījumu veidā.

Promocijas darba mērķa sasniegšanai tika izvirzīti šādi uzdevumi:

1. Veikt hipotēkas institūta vēsturiskās attīstības izpēti un aprakstu - no Senās Romas klasisko romiešu tiesību laika (1. līdz 3. gs.) līdz mūsdienām.

2. Veikt hipotēkas institūta saturisko izpēti.

3. Veikt hipotēkas institūta salīdzinošo apskatu ar ASV, kur atsevišķos štatos pastāv bezregresa hipotekāro kredītu regulējums.

4. Analizēt tiesību doktrīnu saistībā ar hipotēkas institūtu.

5. Analizēt tiesu praksi ar hipotēku saistītajās lietās.

6. Konstatēt problēmu jautājumus un izvirzīt priekšlikumus to novēršanai.

Pētījuma objekts ir civiltiesību sistēmā pastāvošā tiesību subjektu attiecību sistēma, kurā hipotēkas institūts pastāv. Pētījuma priekšmets ir hipotēkas institūta tiesiskais regulējums.

Pētījuma jautājumi ir izvirzīti nolūkā sasniegt pētījuma mērkị: 
1. Kā vēsturiski ir attīstījies hipotēkas institūts un kā tas ir pārṇemts Latvijas tiesībās?

2. Kāds ir hipotēkas institūta saturs - mērķis, principi, realizācijas process, un vai šajos hipotēkas institūta satura elementos ir nepieciešami uzlabojumi?

3. Kāds ir bezregresa hipotekāro kredītu tiesiskais regulējums ASV un vai Latvijā ieviestais tiesiskais regulējums ir uzskatāms par bezregresa hipotekāro kredītu regulējumu?

4. Kādi ir iespējamie hipotēkas institūta pilnveidošanas virzieni un iespējas Latvijas tiesībās?

Pētījuma metodes. Lai izpildītu promocijas darba uzdevumus un sasniegtu promocijas darba mērķi, autors pētījumā izmanto vispārējās zinātniskās pētījumu metodes: vēsturisko metodi, analīzi, abstrakciju, salīdzinošo metodi, induktīvo un deduktīvo metodi, kā arī tiesību normu iztulkošanas metodes - teleologiisko, sistēmisko, vēsturisko un gramatisko iztulkošanas metodi.

Promocijas darba rezultātu aprobācija un publicēšana. Pētījuma rezultāti, prezentējot atsevišş̧us problēmu jautājumus un to iespējamos risinājumus, ir aprobēti šādās konferencēs un publikācijās:

1. tabula

Promocijas darba rezultātu aprobācija

\begin{tabular}{|c|}
\hline Mutiski referēti vietēja mēroga zinātniskajās konferencēs Latvijā \\
\hline 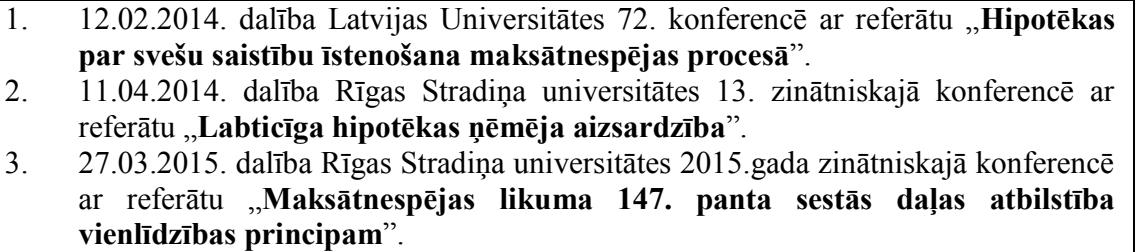 \\
\hline
\end{tabular}




\section{1. tabulas turpinājums}

\begin{tabular}{|c|c|}
\hline \multicolumn{2}{|r|}{ Mutiski referāti starptautiskās zinātniskajās konferencēs } \\
\hline 1. & $\begin{array}{l}\text { 11.04.2014. dalība Daugavpils universitātes 56.starptautiskajā zinātniskajā } \\
\text { konferencē ar referātu „Tiesiskās plānošanas dokumenti saistībā ar hipotēkas } \\
\text { institūtu”. }\end{array}$ \\
\hline 2. & $\begin{array}{l}\text { 23.04.2014. dalība Rīgas Stradiņa universitātes starptautiskajā praktiskajā } \\
\text { konferencē „Tiesiskā politika sabiedrības attīstībai” ar referātu „Atseviškas } \\
\text { galvojuma pilnveidošanas iespējas”. }\end{array}$ \\
\hline 3. & $\begin{array}{l}\text { 15.05.2014. dalība Baltijas Starptautiskās akadēmijas organizētajā IV } \\
\text { starptautiskajā jauno pētnieku un studentu zinātniski praktiskajā konferencē } \\
\text { „Izaicinājumi un iespēju laiks: problēmas, risinājumi, perspektīvas” ar } \\
\text { referātu „Bez regresa hipotekārie kredīti ASV”. }\end{array}$ \\
\hline 4. & $\begin{array}{l}\text { 27.11.2014. dalība Rīgas Stradina universitātes starptautiskajā starpdisciplinārajā } \\
\text { konferencē „Society Health Welfare” ar referātu „Mājokḷa atbalsta programma } \\
\text { - cerības un realitāte”. }\end{array}$ \\
\hline 5. & $\begin{array}{l}\text { 12.12.2014. dalība Baltijas Starptautiskās akadēmijas organizētajā starptautiskajā } \\
\text { zinātniski praktiskajā konferencē “Transformācijas process tiesībās, regíonālajā } \\
\text { ekonomikā un ekonomiskajā politikā: ekonomiski - politisko un tiesisko attiecību } \\
\text { aktuālās problēmas” ar referātu „Maksātnespējas likuma 147.panta grozījumu } \\
\text { atbilstība LR Satversmes 105.pantam”. }\end{array}$ \\
\hline 6. & $\begin{array}{l}\text { 17.04.2015. dalība Daugavpils Universitātes } 57 . \text { starptautiskajā zinātniskajā } \\
\text { konferencē ar referātu „Hipotēkas izveidošanās romiešu tiesībās”. }\end{array}$ \\
\hline 7. & $\begin{array}{l}\text { 23.04.2015. dalība Rīgas Stradiņa universitātes starptautiskajā zinātniskajā } \\
\text { konferencē „Drošības nostiprināšanas aktuālās problēmas: politiskie, sociālie, } \\
\text { tiesiskie aspekti” ar referātu „Iedzīvotāju finanšu izglītošanas nozīmīgums } \\
\text { finanšu drošības garantēšanā”. }\end{array}$ \\
\hline 8. & $\begin{array}{l}\text { 03.07.2015. dalība "Second European Academic Research Conference on Global } \\
\text { Business, Economics, Finance and Banking” Cīrihē, Šveicē, ar referātu „Banking } \\
\text { Loan Recovery Issues in Latvia”. }\end{array}$ \\
\hline 9. & $\begin{array}{l}\text { 11.12.2015. dalība Baltijas Starptautiskās akadēmijas organizētajā IV } \\
\text { starptautiskajā zinātniski praktiskajā konferencē „Transformācijas process tiesībās, } \\
\text { regionālajā ekonomikā un ekonomiskajā politikā: ekonomiski - politisko un } \\
\text { tiesisko attiecību aktuālās problēmas” ar referātu „Galvojuma akcesoritātes } \\
\text { principa izṇēmumi”. }\end{array}$ \\
\hline 10. & $\begin{array}{l}\text { 20.04.2016. dalība Rīgas Stradiņa universitātes starptautiskajā zinātniski } \\
\text { praktiskajā konferencē "Mūsdienu sabiedrības jaunie izaicinājumi drošības } \\
\text { nostiprināšanā: reālais stāvoklis un perspektīvas” ar referātu „Fiktīvu îres līgumu } \\
\text { problemātika”. }\end{array}$ \\
\hline 11. & $\begin{array}{l}\text { 23.08.2016. dalība „3 } 3^{\text {rd }} \text { International Multidisciplinary Scientific Conference on } \\
\text { Social Sciences \& Arts SGEM 2016" Albenā, Bulgārijā, ar referātu „Real } \\
\text { Encumbrance Institute in Civil Law of the Republic of Latvia”. }\end{array}$ \\
\hline 12. & $\begin{array}{l}\text { 23.08.2016. dalība „,3 } 3^{\text {rd }} \text { International Multidisciplinary Scientific Conference on } \\
\text { Social Sciences \& Arts SGEM 2016” Albenā, Bulgārijā, ar referātu „Fictitious } \\
\text { Lease Agreements Issue in Loan Recovery Processes in Latvia”. }\end{array}$ \\
\hline
\end{tabular}




\section{1. tabulas turpinājums}

13. 24.11.2017. dalība Rīgas Stradiṇa universitātes organizētajā konferencē ", $6^{\text {th }}$ International interdisciplinary scientific conference Society. Health. Welfare 2016." ar referātu "Fictitious Employment Contracts Issue in Loan Recovery Processes in Latvia".

Publikācijas (tēzes) vietēja mēroga konferenču rakstu krājumos

1. „Labticīga hipotēkas n̦ēmēja aizsardzība” - tēzes 10.-11.04.2014. Rīgas Stradiṇa universitātes 13. zinātniskajā konferencē. Pieejams:

http://www.rsu.lv/images/stories/zk2014/Labticiga_hipotekas_nemeja_aizsardziba .pdf (ISBN 978-9984-793-52-8)

2. „Atsevišķas galvojuma pilnveidošanas iespējas” - tēzes 23.04.2014. Rīgas Stradiņa universitātes zinātniskajā konferencē „Tiesiskā politika sabiedrības attīstībai”. Pieejams:

http://www.rsu.lv/eng/images/Documents/Publications/legal policy conference a bstracts.pdf (ISBN 978-9984-793-55-9; 65-67.lpp.)

3. „Maksātnespējas likuma 147. panta sestās daḷas atbilstība vienlīdzības principam" - tēzes 27.03.2015. Rīgas Stradiņa universitātes 2015.gada zinātniskajā konferencē. Pieejams:

http://www.rsu.lv/images/stories/zk2015/maksatnespejas_likums_147_pants_vienl idzibas_princips.pdf.

4. „Hipotēkas izveidošanās romiešu tiesībās” - tēzes 17.04.2015. Daugavpils Universitātes 57. starptautiskajā zinātniskajā konferencē. Pieejams:

http://dukonference.lv/files/proceedings_of conf/2015 978-9984-14-7161_DU_57_starpt\%20zinatn_konf_tezes.pdf (ISBN 978-9984-14-716-1; 71.1pp.).

5. „Iedzīvotāju finanšu izglītošanas nozīmīgums finanšu drošības garantēšanā"

- tēzes 23.04.2015. Rīgas Stradiña universitātes RSU starptautiskajā zinātniskajā konferencē. Pieejams:

www.rsu.lv/images/stories/dokumenti/bukleti/drosibas_nostiprinasana_konf_tezes _apr2015.pdf (ISBN 978-9984-793-72- 6; 79.-80.lpp.).

Publikācija (raksts) starptautiska mēroga konferences rakstu krājumā ārpus Latvijas

1. Referāts „Banking Loan Recovery Issues in Latvia” ir publicēts konferences

"Second European Academic Research Conference on Global Business,

Economics, Finance and Banking” zinātnisko rakstu krājumā. Pieejams:

http://globalbizresearch.org/Swiss_Conference/Conference_Papers.php (ISBN:

978-1-63415-477-2).

Publikācijas (raksti) recenzējamos zinātniskajos izdevumos Latvijā un ārvalstīs

1. Raksta „Bez regresa hipotekārie kredīti ASV” publikācija Baltijas Starptautiskās akadēmijas organizētās IV starptautiskās jauno pētnieku un studentu zinātniski praktiskās konferences „Izaicinājumi un iespēju laiks: problēmas, risinājumi, perspektīvas" rakstu krājumā (ISBN kods 978-9984-47091-7). 
2. Raksts „Tiesiskās plānošanas dokumenti saistībā ar hipotēkas institūtu” publicēts Daugavpils universitātes 56.starptautiskās zinātniskās konferences rakstu krājumā. Pieejams: http://www.dukonference.lv/files/proceedings_of_conf/9789984-14-702-4_56\%20konf\%20kraj_B_Soc\%20zin.pdf (ISBN 978-9984-14-7024; 174.-180.lpp.). Iekl̦auts EBSCO Host datu bāzē.

3. Raksts „Maksātnespējas likuma 147. panta grozījumu atbilstība LR Satversmes 105. pantam" publicēts Baltijas Starptautiskās akadēmijas organizētās starptautiskās zinātniski praktiskās konferences "Transformācijas process tiesībās, reǵionālajā ekonomikā un ekonomiskajā politikā: ekonomiski politisko un tiesisko attiecību aktuālās problēmas" III Starptautiski zinātniski praktiskās konferences rakstu krājumā (ISBN 978-9984-47-099-3).

4. Raksts „Hipotēkas akcesoritātes principa izṇēmumi” publicēts Starptautiskā zinātniskā foruma, XVI Starptautiskās zinātniskās konferences Biznesa augstskolā Turība „Gudra, ilgtspējīga un iesaistoša Eiropa: izaicinājums attīstībai” rakstu krājumā. Pieejams: http://www.turiba.lv/f/XVI_konf.raksti_FINAL.pdf (ISSN 1691-6069; 238.-245.lpp.). Iekḷauts EBSCO Host datu bāzēe.

5. Raksts „Galvojuma akcesoritātes principa izṇēmumi” publicēts IV. Starptautiskās zinātniski praktiskās konferences "Transformācijas process tiesībās, reǵionālajā ekonomikā un ekonomiskajā politikā: ekonomiski - politisko un tiesisko attiecību aktuālās problēmas" zinātnisko rakstu krājumā. Pieejams: http://bsa.edu.lv/docs/konf11122015.pdf ～(ISBN 978-9984-47-108-2; 305.310.lpp.).

6. Raksts „Fictitious Lease Agreements Issue in Loan Recovery Processes in Latvia" publicēts, $3^{\text {rd }}$ International Multidisciplinary Scientific Conference on Social Sciences \& Arts SGEM 2016" rakstu krājumā (ISBN 978-619-7105-73-5, ISSN 2367-5659; 631.-638.1pp.), kas tiks izvietots Thomson Reuters, ISI Web of Knowledge, ISI Web of Science, CrossRef, ProQuest, EBSCOHost un Google Scholar datubāzēs.

7. Raksts „Real Encumbrance Institute in Civil Law of the Republic of Latvia” publicēts, $3^{\text {rd }}$ International Multidisciplinary Scientific Conference on Social Sciences \& Arts SGEM 2016" rakstu krājumā (ISBN 978-619-7105-73-5, ISSN 2367-5659; 761.-768.lpp.), kas tiks izvietots Thomson Reuters, ISI Web of Knowledge, ISI Web of Science, CrossRef, ProQuest, EBSCOHost un Google Scholar datubāzēs.

8. Raksts "Fictitious Employment Contracts Issue in Loan Recovery Processes in Latvia" ir pieṇemts publicēšanai Rīgas Stradiṇa universitātes organizētās konferences, $6^{\text {th }}$ International interdisciplinary scientific conference Society. Health. Welfare 2016." rakstu krājumā, kas tiks izvietots Thomson Reuters datu bāzē.

Promocijas darba rezultāti ir aprobēti ne tikai zinātniskajās konferencēs un rakstu krājumos, bet tiem ir arī praktiska aprobācija. Autors darbojas biedrībā „Latvijas Komercbanku asociācija”, pārstāvot biedrības biedru (banku) 
intereses dažādās likumdošanas darba grupās, tajā skaitā Tieslietu ministrijas izveidotajā Maksātnespējas likuma grozījumu darba grupā. Viena no autora iniciatīvām attiecībā uz nodrošinātā kreditora statusu maksātnespējas procesos ${ }^{2}$ ir iestrādāta un pieņemta Maksātnespējas likuma ${ }^{3}$ 7. panta pirmajā daḷā ar Maksātnespējas likuma 2014. gada 25. septembra grozījumiem. ${ }^{4}$

Promocijas darbā izvirzītos priekšlikumus normatīvo aktu grozījumiem, lai stiprinātu hipotēkas institūtu, autors ir iesniedzis biedrībā „Latvijas Komercbanku asociācija”, kas tos tālāk iesniegs gan atbildīgo ministriju (Tieslietu ministrijas, Ekonomikas ministrijas un Finanšu ministrijas) izveidotajās darba grupās, gan atbildīgajās Saeimas komisijās (Juridiskajā komisijā, Tautsaimniecības, agrārās, vides un regiionālās politikas komisijā un Aizsardzības, iekšlietu un korupcijas novēršanas komisijā). Autors pats piedalīsies šo darba grupu sanāksmēs, lai likumdošanas ceḷā censtos panākt atbilstošu grozījumu pieņemšanu normatīvajos aktos.

2 Noteikt, ka nodrošinātā kreditora statuss attiecināms ne tikai uz maksātnespējīgā parādnieka saistībām, bet arī uz trešās personas saistībām, kā arī paredzēt, ka tieši publiska ķ̣̂la uz maksātnespējīgā parādnieka mantu (neatkarīgi no tā, kā saistības ir nodrošinātas - parādnieka vai trešās personas) ir pamats nodrošinātā kreditora statusa noteikšanai kreditoram.

${ }^{3}$ Maksātnespējas likums: Latvijas Republikas likums. Latvijas Vēstnesis, 124 (4316), 06.08.2010.

${ }^{4}$ Grozījumi Maksātnespējas likumā: Latvijas Republikas likums. Latvijas Vēstnesis, 204 (5264), 15.10.2014. 


\section{HIPOTĒKAS INSTITŪTA VĒSTURISKĀ ATTĪSTİBA UN HIPOTĒKAS INSTITŪTA SATURS}

\subsection{Hipotēkas institūta vēsture}

Klasiskajās romiešu tiesībās (1. līdz 3. gs. $)^{5}$ radās ķīlas tiesību institūts hypotheca ${ }^{6}$ jeb hipotēka. Ideja par hipotēku, kā reālu nodrošinājumu neatkarīgi no kreditora valdījuma, iespējams, ir aizgūta no Grieķijas. Romieši zināja par grieķu hipotēku, redzēja tās darbību provincēs, un viennozīmīgi aizguva grieķu vārdu hypothec. ${ }^{7}$ Sākumā ar to apzīmēja baltus ${ }^{8}$ stabus, kas tika uzstādīti uz zemes gabala robežām, lai publiski norādītu, ka attiecīgais zemes gabals ieķīlāts. Senajā Grieķijā un Senajā Romā korroborācija tagadējā nozīmēe nepastāvēja. Lai tiktu nodrošināts publicitātes princips un neciestu trešo personu intereses, kas par ieķīlāšanu katrā atsevišķā gadījumā nevarēja zināt, tika uzstādīiti minētie akmens stabi, tādējādi izdarot tā saucamo „reālo korroborāciju". ${ }^{9}$ Uz akmens stabiem bija uzraksts par parāda summu un tos cēla kreditori. $^{10}$

Hipotēku varēja nodibināt ar vienkāršu vienošanos par lietas ieķīāăšanu starp parādnieku un kreditoru bez lietas nodošanas. Lieta ķīlas pastāvēšanas

5 Kalniņš V. Romiešu civiltiesību pamati. 1977. gadā publicētās grāmatas faksimilizdevums. Rīga: Apgāds Zvaigzne ABC, 2010, 26., 124. lpp.

${ }^{6}$ Kalniņš V. Romiešu ķīlu tiesību attīstība. Jurists, 01.03.1939., Nr. 3/4 (97/98), 49. sleja.

${ }^{7}$ Jackson T.C. Justian's Digest (Book 20) with an English Translation and an Essay on the Law of Mortgage in the Roman Law. London: Sweet and Maxwell, Limited, 1908. Reproduction: Lavergne: Gale, 2014, p. xxviii.

${ }^{8}$ Cakste K. Civiltiesības. Lekcijas. Raksti. Rīga: Zvaigzne ABC, 2011, 123. lpp.

${ }^{9}$ Sinaiskis V. Latvijas civiltiesību apskats. Lietu tiesības. Rīga: L.U. Studentu padomes grāmatnīcas izdevums, 1940, 58. 1pp.

${ }^{10}$ Grīns A. (red.). Pasaules vēsture. I daḷa. Senie laiki. Rīga: Grāmatu draugs, 1929, 175. lpp. 
laikā palika parādnieka rokās - īpašumā un valdījumā, kas deva iespēju viņam to joprojām saimnieciski izmantot. ${ }^{11}$

Uz vienu un to pašu lietu, piemēram, īpašumu, māju, varēja nodibināt vairākas hipotēkas - par labu vienam kreditoram, otram, trešajam utt. Neliekot šķēršlus šādai vairākkārtīgai ieķ̄ilāšanai, kas bieži bija nepieciešama dažādos saimnieciskajos darījumos, romiešu tiesībās tika ieviests prioritātes princips: vispirms tika apmierināta laika ziṇā pirmā hipotēka, tad otrā utt. ${ }^{12}$

Novērtējot hipotēkas institūtu no ķīlu tiesiskā viedokḷa, to var atzīt par ķ̄ilu tiesību vārda pilnā nozīmē. Te spilgti parādās kā lietu tiesiskais raksturs (lietu tiesība uz svešu lietu), tā arī akcesoriskā daba (atkarība no parāda saistības pastāvēšanas). ${ }^{13}$ Galvenā atšksirība starp mūsdienu hipotēku un romiešu tiesību hipotēku ir hipotēkas priekšmets - romiešu tiesībās hipotēkas priekšmets varēja būt gan kustama, gan nekustama manta, bet mūsdienās hipotēkas priekšmets ir tikai nekustama manta (nekustamais īpašums).

Romiešu tiesību pārṇemšana un pielietošana praksē kontinentālajā Eiropā (veidojās romāṇu - germāṇu tiesību sistēma) norisinājās trīs posmos: 1) līdz 13. gs. Eiropas dienvidos saglabājās romiešu tiesiskās kultūras elementi. Tika izmantoti vienkāršoti romiešu tiesību avoti (piem., 5. gs. rietumgotu karaļa Alarika pieņemtais „Alarika breviārijs”); 2) 13.-17. gs. (universitāšu posms) Ziemel̦itālijas universitātēs pēta un pasniedz romiešu tiesības, pamatojoties uz Justiniāna kodifikāciju. Izveidojās romiešu tiesību skolas. 14.-15. gs. romiešu tiesības kontinentālajā Rietumeiropā atzina par spēkā esošām, tās vai nu pielāgojot (postglosatori) vai pārņemot pilnībā (kā Vācijā); 3) pēc 17., 18. gs.

\footnotetext{
11 Kalniņš V. Romiešu civiltiesību pamati. 1977. gadā publicētās grāmatas faksimilizdevums. Rīga: Apgāds Zvaigzne ABC, 2010, 124. lpp.

12 Покровский И.А. История римского права. Iegūts no: http://civil.consultant.ru/elib/books/25/page_42.html [sk. 17.03.2016.].

13 Kalniņš V. Romiešu ķīlu tiesību attīstībă. Jurists, 01.03.1939., Nr. $3 / 4$ (97/98), 53. sleja.
} 
revolūcijām Eiropas valstu tiesībās tiek pārṇemti romiešu tiesību institūti (piemēram, Napoleona civilkodeksā 19. gs. sākumā). ${ }^{14}$

1864. gada 12. novembrī Krievijas imperators Aleksandrs II apstiprināja Tērbatas universitātes profesora Frīdriha Georga fon Bunges sastādīto Baltijas provinču tiesību kodifikācijas trešo daļu - Livonijas, Igaunijas un Kurzemes privāttiesības (vācu valodā - Liv-Est-und Curlaendisches Privatrecht, krievu valodā - Сводъ гражданскихъ узаконеній губерній Остзейскихъ). ${ }^{15}$ Atbilstoši imperatora rīkojumam Baltijas likumu kopojuma trešā daļa jeb Vietējo civillikumu kopojums stājās spēkā 1865. gada 1. jūlijā. ${ }^{16}$

Vietējo civillikumu kopojuma nozīmīgākais avots bija romiešu tiesības un pandektu tiesības. ${ }^{17}$ Bunges izstrādātais Vietējo civillikumu kopojums sastāvēja no 4600 pantiem, no kuriem 2882 panti saturēja romiešu tiesību normas. $^{18}$

1937. gada 28. janvārī pieņemtais LR Civillikums ${ }^{19}$ (turpmāk Civillikums) tika izstrādāts uz Vietējo civillikumu kopojuma bāzes, ${ }^{20}$ kas pēc Latvijas neatkarības atjaunošanas ar trīs atsevišķiem likumiem ${ }^{21}$ tika atjaunots

${ }^{14}$ Lazdinš J., Osipova S. Latvijas un Eiropas viduslaiku tiesību vēsturē sastopamie jēdzieni un to skaidrojumi. Rīga: LU tipogrāfija, 1996, 14. lpp.

${ }^{15}$ Gailīte D. Frīdrihs Georgs fon Bunge. Jurista Vārds, 11.11.2014., Nr. 44/45 (846/847), 10. lpp.

${ }^{16}$ Пахман С. В. Исторія кодификаиіи гражданскаго права въ двухъ томахъ. Томъ II. С.-Петербургъ, 1876, 346. стр.

${ }^{17}$ Lazdin̦š J. Baltijas Civillikums laikmetu griežos: likuma pieņemšanas 150 gadu jubilejas atcerei. Jurista Vārds, 11.11.2014., Nr. 44/45 (846/847), 20. lpp.

${ }^{18}$ Sal.: Švābe A. Jaunais Civīllikums latvju tiesību vēstures gaismāa. Prezidenta Ulmaņa Civīllikums. Rakstu krājums. Rīga: Pagalms, 1938, 109. lpp.; Kalninš̌ V. Romiešu tiesību nozìme mūsu laikos. Novilkums. Jurists, 1939., Nr. 7/8(101/102), Rīga: b.i., 1940, 18. lpp.

${ }^{19}$ Latvijas Republikas likums Civillikums. Valdības Vēstnesis, 41, 20.02.1937.

${ }^{20}$ Kalniņš E. Ievads grāmatai: Vīnzarājs N. Civiltiesību problēmas. Raksti (1932.1939.). Rīga: Erlena Kalniņa un Viktora Tihonova izdevums, 2000, 10.lpp.

21 Likums „Par atjaunotā Latvijas Republikas 1937. gada Civillikuma ievada, mantojuma tiesību un lietu tiesību daļas spēkā stāšanās laiku un kārtību": Latvijas Republikas likums. Ziņotājs. 29/31, 30.07.1992.; likums „Par atjaunotā Latvijas Republikas 1937. gada Civillikuma saistību tiesību daļas spēkā stāšanās laiku un 
1992. un 1993. gadā. Tādējādi mūsdienās spēkā esošais Civillikums lielā mērā satur romiešu tiesību institūtus, tajā skaitā hipotēkas institūtu.

\subsection{Hipotēkas vieta ķīlu sistēmā un hipotēkas sekas}

Uz hipotēku attiecas ne tikai hipotēkas speciālās tiesību normas un speciālie principi, bet arī tie tiesību normas un principi, kas kopīgi visām ķīlu tiesībām. $^{22}$

Civillikuma 1278. pants nosaka, ka ķ̄ilas tiesība ir tāda tiesība uz svešu lietu, uz kuras pamata šì lieta nodrošina kreditoram viṇa prasījumu tādā kārtā, ka viņš var no tās dabūt šā prasījuma samaksu. No šīs definīcijas ir skaidrs, ka ķ̄ilas tiesības mērķis ir prasījuma nodrošināšana tādā veidā, lai kreditors no ķīlas var dabūt prasījuma samaksu. Ar to tiek radīts reāls nodrošinājums pretēji personīgiem nodrošinājumiem. ${ }^{23}$

Hipotēka ir visbiežāk izmantotais ķīlu veids. Tas saistîts ar hipotēkas izmantošanu kā vienu no drošākajiem ķīlas veidiem banku kredītu darījumos. Kopš 1993. gada sākuma līdz 2017. gada 16. janvārim zemesgrāmatās ir iesniegti 630899 nostiprinājumu lūgumi hipotēku nodibināšanai. ${ }^{24}$ Savukārt otrs plašāk izmantotais ķ1̄lu veids ir komercķ̄ilas - kopš 1998. gada ir reǵistrētas 177175 komercķīlas. $^{25}$ Salīdzinot, kopš 1998. gada ir iesniegti

kārtību”: Latvijas Republikas likums. Ziņotājs. 1/2, 14.01.1993.; likums „Par atjaunotā Latvijas Republikas 1937. gada Civillikuma ǵimenes tiesību daļas spēkā stāšanās laiku un kārtību": Latvijas Republikas likums. Latvijas Vēstnesis, 35, 08.06.1993., Ziņotājs, 22/23, 10.06.1993.

${ }^{22}$ Bez hipotēkas arī - komercķīlai, lietošanas ķīlai, rokas ķīlai, finanšu ķīlai un kuǵu hipotēkai.

${ }^{23}$ Čakste K. Civiltiesības. Lekcijas. Raksti. Rīga: Zvaigzne ABC, 2011, 123. lpp.

24 Statistika par darījumiem zemesgrāmatu nodaḷās. Valsts vienotā datorizētā zemesgrāmata. Iegūts no: https://www.zemesgramata.lv/lv/Home/Statistics [sk. 16.01.2017.].

25 Komercķīlu reǵistrācijas dinamika. Lursoft statistika. Iegūts no: https://www.lursoft.lv/lursoft_statistika/?\&id=63 [sk. 16.01.2017.]. 
624769 nostiprinājuma lūgumi hipotēku nostiprināšanai, ${ }^{26}$ tas ir, 3,5 reizes vairāk, nekā ir nodibinātas komercķīlas.

Hipotēkai kā vienam no ķīlas tiesību veidiem ir gan savi tiesību principi, gan kopējie ķ̄ilas tiesību principi, kas nosaka hipotēkas kā ķīlas saturu un realizēšanas kārtību.

A. Ķīlas akcesoritātes princips. Ķīlu tiesības atšķiras no citām lietu tiesībām ar to, ka tām ir tikai akcesorisks (blakus) raksturs, tas ir, ka tās patstāvīgi nevar eksistēt. Neatkarīgi no prasības tās nav iedomājamas, jo to uzdevums ir nodrošināt prasību un tamdēl ķ̄ilu tiesības pastāv tik tālu, cik tālu pastāv pati prasība, - ja prasība izbeidzas - izbeidzas arī ķīlas tiesība. ${ }^{27}$

B. Ķīlas nedalāmības princips - ķ̄ilas tiesība paliek spēkāà tik ilgi, kamēr pilnīgi apmierināts kreditors, kuram tādēl ķ̄ila atbild pēc dą̧as samaksas arī vēl par nesamaksāto parāda dal̦u. Ja prasījums nodrošināts ar ķīlas tiesību uz vairākām lietām un nodrošināts tikai pa daļai, tad kreditors patur ķ̄ilas tiesību uz visām ieķ̄ilātām lietām, tāpēc, ka katra no tām visā sastāvā atbild par viņa prasījumu (Civillikuma 1286., 1287. pants). ${ }^{28}$

C. Ķīlas absolūtuma princips. Izejot no romiešu ķ̄ilas tiesību konstrukcijas, ķ̄ilas tiesība attiecībā uz ieķīlāto objektu ir ius in re aliena (no latīṇu valodas - lietu tiesības uz svešu lietu). Tas nozīmē, ka kreditoram pieder lietu tiesība realizēt savu prasījumu ar ieķîlātā priekšmeta pārdošanu. Ķ̄ilas tiesību kreditoram ir tiesiska iespēja realizēt nodrošinājumu, neraugoties uz to, kādās rokās atrodas nodrošinājuma priekšmets. Šì kreditora tiesiskā iespēja ir

\footnotetext{
26 Statistika par darījumiem zemesgrāmatu nodaļās. Valsts vienotā datorizētā zemesgrāmata. Iegūts no: https://www.zemesgramata.lv/lv/Home/Statistics [sk. 16.01.2017.].

${ }^{27}$ Lēbers A. Civiltiesības un civilprocess: kara juridiskos kursos lasīto lekciju konspekts. Rīga: 1921, 56. lpp.

${ }_{28}$ Sinaiskis $V$. Latvijas civiltiesību apskats. Lietu tiesības. Saistību tiesības. Rīga: Latvijas juristu biedrība, 1995, 77. lpp.
} 
absolūta. Sakarā ar to ķīlas tiesībām uz nekustamo īpašumu jābūt reǵistrētām publiskās zemesgrāmatās. ${ }^{29}$

D. Saistības patstāvība. Saistība starp pusēm vienmēr ir patstāvīga tās spēku neietekmē nodrošinājumu esamība vai neesamība. Nodrošinājumi neatkarīgi no to veida (reāli (lietiski) - ķīlas, t.sk. hipotēkas; relatīvi (personiski) - galvojums, rokas nauda, līgumsods) vienmēr ir blakus tiesības, tas ir, akcesoriskas tiesības. Ja tiek izpildīta saistība, tad beidz pastāvēt arī nodrošinājumi.

E. Ķīlas atbildības apmērs. Saskaņā ar Civillikuma 1290. pantu, ja nav noteikti norunāts pretējais, ķīlas tiesība nodrošina ne vien galveno prasījumu, bet arī ar to saistītos blakus prasījumus. No tā izriet būtisks ķīlas tiesību princips - ķīlas tiesība nodrošina gan galveno prasījumu, gan arī ar to saistītos blakus prasījumus: procentus, nepieciešamos izdevumus, ${ }^{30}$ līgumsodu, zaudējumus.

F. Hipotēkas pirmtiesība. Uz vienu ķīlas priekšmetu var būt vairāki kreditori. Attiecībā uz hipotēku jāizšksir kreditoru pirmtiesība, otra, trešā utt. tiesība; priekšrocības ir tam kreditoram, kas savu tiesību agrāk nostiprinājis zemesgrāmatā. ${ }^{31}$

Ar jaunu, vēlāku hipotēku ierakstišanu zemesgrāmatā iepriekšējiem hipotēkas kreditoriem nekādi pārpratumi nevar rasties, jo, pārdodot īpašumu publiskā izsolē, ar hipotēku nodrošinātos prasījumus apmierina pēc pirmtiesībām, ko nosaka pēc hipotēkas ierakstīšanas laika zemesgrāmatu reg̣istrā. ${ }^{32}$ Tas nozīmē, ka vecākas hipotēkas tiek apmierinātas pirms jaunākām.

29 Sinaiskis V. Latvijas civiltiesību apskats. Lietu tiesības. Saistību tiesības. Rīga: Latvijas juristu biedrība, 1995, 76. 1pp.

${ }^{30}$ Ibid., 77. 1pp.

${ }^{31}$ Ibid.

${ }^{32}$ Bukovskis V. Civīlprocesa mācības grāmata. Rīga: Autora izdevums, 1933, 633. lpp. 
G. Zemesgrāmatu publiskās ticamības princips. Saskaņā ar Zemesgrāmatu likuma ${ }^{33} 1$. pantu zemesgrāmatās ieraksta nekustamus īpašumus un nostiprina ar tiem saistītās tiesības. Zemesgrāmatas ir visiem pieejamas, un to ierakstiem ir publiska ticamība.

H. Hipotēkas specializācijas princips. Hipotēkas specializācijas princips ir ietverts Civillikuma 1373. pantā, kas nosaka, ka hipotēku ieraksta zemesgrāmatās uz noteiktu nekustamo īpašumu, par kura īpašnieku apzīmēts šajās grāmatās ieķīātājs. No minētā izriet, ka par hipotēkas priekšmetu var būt tikai individuāli nosakāma lieta, tādējādi netiek piel̦auta generālhipotēka uz visu īpašumu. ${ }^{34}$

Civillikuma 1278. pants nosaka, ka ķīlas tiesība ir tāda tiesība uz svešu lietu, uz kuras pamata šì lieta nodrošina kreditoram viņa prasījumu tādā kārtā, ka viņš var no tās dabūt šā prasījuma samaksu. Savukārt saskaṇā ar Civillikuma 1319. pantu ķ̄ilas ņēmējs, kuru parādnieks nav noteiktā laikā apmierinājis, var meklēt sev apmierinājumu no ieķīlātās lietas un šajā nolūkā spert visus vajadzīgos soḷus tās pārdošanai. No šīm ķīlu tiesību pamatnormām izriet ķ̄ilas būtība - kreditora prasības nodrošinājums, ko kreditors var realizēt tikai parādnieka saistības nepildīšanas gadījumā. Gan no šīm un citām ķ̣̂las regulējošām vispārējām tiesību normām, gan no hipotēku regulējošām speciālajām tiesību normām izriet noteiktas sekas, kas raksturīgas hipotēkai.

Hipotēkas tiesiskās sekas atšķiras ķ̄ilas no tiesības sekām ar atvieglināto pierādīšanas iespēju, ar to saistîto paātrināto piedziņas veidu un ar priekšrocībām maksātnespējas procesā. Materiāltiesiskā ziṇā arī šajā procesāa

\footnotetext{
${ }^{33}$ Zemesgrāmatu likums: Latvijas Republikas likums. Ziņotājs. 16, 29.04.1993., Likumu un noteikumu krātuve. 38, 30.12.1937.

${ }^{34}$ Краснокутский В. А. Мъстное гражданское право губерній прибалтійскихъ и привислянскихъ. Пособіе къ лекціямъ. Москва: Типографія Императорскаго Московскаго Университета, 1910, 124. стр.
} 
pię̧aujamas tās pašas ierunas un tiesiskie apstrīdēšanas līdzekḷli kā jebkurā procesā par k̦īlas tiesībām. ${ }^{35}$

Hipotēkas nostiprināšanas zemesgrāmatā sekas ir: 1) lietu tiesību rašanās; 2) nostiprināto tiesību neapstrīdamība; 3) saistošais raksturs visiem; 4) pirmtiesības rašanās; ${ }^{36}$ 6) kreditora tiesības uzsākt bezstrīdus piespiedu izpildīšanu saistību neizpildes gadījumā; 7) kreditora tiesības pārdot ķ̄las priekšmetu labprātīgā izsolē par brīvu cenu, ja šāda tiesība pielīgta hipotēkas līgumā; 8) kreditora aizsardzība, ja pret ieķ̄īâto īpašumu tiek vērsti citi prasījumi; 9) nodrošinātā kreditora statuss parādnieka (ieķīātāja) maksātnespējas procesā, tiesiskās aizsardzības procesā vai ārpustiesas tiesiskās aizsardzības procesā. ${ }^{37}$

${ }^{35}$ Rozenfelds J. Lietu tiesības. 4. labotais, papildinātais izdevumus. Rīga: Zvaigzne ABC, 2011, 186. lpp.

${ }^{36}$ Краснокутский В. А. Мъстное гражданское право губерній прибалтійскихъ и привислянскихъ. Пособіе къ лекиіямъ. Москва: Типографія Императорскаго Московскаго Университета, 1910, 88. стр.

${ }^{37}$ Tiesiskās aizsardzības process un ārpustiesas tiesiskās aizsardzības process var būt tikai juridiskām personām, līdz ar to parādnieks (ieķīāâājs) šajā gadījumā vienmēr būs juridiska persona. 


\section{HIPOTĒKAS VISPĀRĒJIE PROBLĒMU JAUTĀJUMI UN TO RISINĀJUMI}

\subsection{Fiktīvie īres līgumi un to mērķis}

Nolūkā kavēt piedziņas procesu, novilcināt laiku jaunā īpašnieka ievešanai nosolītā īpašuma valdījumā, kaitēt hipotēkas kreditoram, kā arī nodrošināt sev un saviem radiniekiem iespēju pēc iespējas ilgāk dzīvot ieḳīātajā dzīvoklī vai dzīvojamā mājāa, par to nemaksājot ne kredīta maksājumus, ne reālus īres maksājumus, negodprātīgi parādnieki mēdz noslēgt fiktīvus īres līgumus ar saviem radiniekiem, svaiṇiem, draugiem vai pazin̄ām. Šādi fiktīvi īres līgumi ir saistoši jaunajam īpašniekam, kas dz̄ivokli vai dzīvojamo māju ir nopircis zvērināta tiesu izpildītāja rīkotajā izsolē.

Ja nekustamā īpašuma nosolītājs ir lūdzis tiesai ievest viņu nosolītā nekustamā īpašuma valdījumā, tiesa, apstiprinot izsoles aktu, lemj par ieguvēja ievešanu nekustamā īpašuma valdījumā (Civilprocesa likuma 613. panta septîtā daļa). Ievešanu valdījumā nodrošina zvērināts tiesu izpildītājs Civilprocesa likuma $74 .^{2}$ nodaḷā noteiktajā kārtībā. Ievedot ieguvēju nekustamā īpašuma valdījumā, tiesu izpildītājs uzaicina parādnieku atbrīvot nekustamo īpašumu no viņam piederošās mantas un atstāt nekustamo īpašumu kopā ar ǵimenes locekḷiem un citām personām, kuras dzīvo kopā ar viṇa ǵimeni (Civilprocesa likuma $620 .{ }^{6}$ panta otrā daļa). Ja pie ievešanas valdījumā tiek konstatēts, ka dzīvoklī vai dzīvojamā mājā uz īres līguma pamata atrodas citas personas, tiesu izpildītājs nav tiesīgs tās izlikt.

Vienīgais veids, kādā tiesiski izlikt fiktīvos īrniekus no nekustamā īpašuma un atzìt fiktīvo īres līgumu par spēkā neesošu, ir celt prasību tiesā par īres līguma atzī̌sanu par spēkā neesošu un fiktīvā îrnieka izlikšanu no nekustamā īpašuma kopā ar īrnieku dzīvojošām personām. 
Gan no autora praktiskās darba pieredzes, gan no tiesu prakses izriet, ka par īres līguma fiktīvo raksturu parasti liecina vairākas pazīmes, kuras sastopamas dažādās kombinācijās: 1) fiktīvi îres līgumi tiek slēgti par dz̄ivojamām mājām vai dzīvokḷiem, pret kuriem tiek vērsta piedziņa - tiesu izpildītājs ir uzsācis piedziņu un nosūtījis paziņojumu par piedziņas vēršanu, vai jau izsludinājis nekustamā īpašuma piespiedu izsoli, vai arī izsole jau ir notikusi un tiesu izpildītājam tiek iesniegts fiktīvais īres līgums; 2) fiktīvi īres līgumi tiek slēgti ar atpakaļejošu datumu; 3) fiktīvi īres līgumi tiek slēgti ar parādnieku radiniekiem, svaiņiem, draugiem un paziņām; 4) fiktīvi īres līgumi tiek slēgti uz ilgu terminuu; 5) īres maksa šādos līgumos ir noteikta nesamērīgi maza; 6) līgumos ir atruna, ka īres maksu îrnieks ir samaksājis skaidrā naudā par ilgu periodu uz priekšu; 7) līgumos ir noteikts, ka komunālos un apsaimniekošanas maksājumus par privātmāju vai dzīvokli maksā izīrētājs; 8) līgumos ir paredzēts ievērojams līgumsods, ja izīrētājs vienpusēji atkāpjas no īres līguma.

Iespēja izmantot fiktīvus īres līgumus pilnībā tiktu izslēgta, ja jaunajam īpašniekam būtu saistoši tikai zemesgrāmatā ierakstīti īres līgumi. Šobrīê Ekonomikas ministrijas pārraudzībā darba grupā ir izstrādāts Dzīvojamo telpu īres likumprojekts, ${ }^{38}$ kura 27. pantā ir paredzēts šis princips. Papildus tam būtu jānosaka, ka gadījumā, ja īpašums ir apgrūtināts ar hipotēku, tad ir nepieciešama hipotēkas kreditora piekrišana īres līguma nostiprināšanai zemesgrāmatā.

\subsection{Fiktīvi darba līgumi}

Bez fiktīviem īres līgumiem vēl viens veids, kā tiek aizskartas hipotēkas kreditora likumīgās intereses, ir fiktīvu darba līgumu noslēgšana par ieķīlātā

${ }^{38}$ Nav publiskots. 
nekustamā īpašuma uzturēšanu un tiesas sprieduma iegūšana par darba algas piedziņu. Saskaņā ar Civilprocesa likuma 628. panta pirmās daļas 1. punktu no naudas, kas saņemta par pārdoto ar ķ1̄lu apgrūtinātu nekustamo īpašumu, vispirms sedzami sprieduma izpildes izdevumi, kas saistīti ar nekustamā īpašuma pārdošanu, pēc tam apmierināmi to darbinieku prasījumi par darba algu izmaksu, kuri saistīti ar nekustamā īpašuma uzturēšanu, un ar viņu darba algām saistîtie sociālās apdrošināšanas maksājumi. Ar hipotēkām nodrošinātie prasījumi tiek segti tikai ceturtajā kārtā (pēc darba algām saistībā ar ieķīlātā īpašuma uzturēšanu, ar īpašumu saistītajiem nodokḷiem un reālnastām, kurām pienācis samaksas termiņš).

Minētā Civilprocesa likuma norma praksē tiek izmantota l̦aunprātīgi. Parādnieks (ieķ̄īātājs), zinādams, ka pret viņam piederošo ieķīlāto īpašumu tiks vērsta piedziņa, jo parādnieks nav pildījis savas saistības pret kreditoru, noslēedz fiktīvu darba līgumu ar kādu draugu vai paziņu par ieķīlātā nekustamā īpašuma uzturēšanu. Darba alga reāli netiek maksāta. Tā vietā tiek izmantota tiesvedība, kā darba algas prasījuma legalizēšanas veids. Fiktīvais darbinieks ceḷ prasību tiesā pret darba devēju (ieķ̄ilātā nekustamā īpašuma īpašnieku) par darba algas par īpašuma uzturēšanu piedziṇu. Tiesas procesā fiktīvais darba devējs atzīst pret viņu celto prasību, kā rezultātā tiesa taisa spriedumu, ar kuru pilnībā tiek apmierināta fiktīvā darbinieka darba algas prasījums. Vēlāk uz tiesas sprieduma pamata tiek izdots izpildu raksts, kas dod fiktīvajam darbiniekam tiesības ar savu prasījumu nostāties pirms hipotēkas kreditora un saņemt līdzekḷus, kas pēc būtības pienākas hipotēkas kreditoram. Ja šādu negodprātīgu shēmu izdodas īstenot, tad iegūtos līdzekḷus ieķīlātājs un fiktīvais darbinieks savā starpā sadala.

Vēsturiski darba algu prioritātes pār hipotēkām mērksis ir bijis nodrošināt ieķīlātā īpašuma uzturēšanu, jo tā īpašnieks par īpašumu pārtrauc rūpēties, tad pie šāda mērķa būtu arī jāatgriežas, izslēdzot iespēju šo prioritāti izmantot ļaunprātīgos nolūkos. 
Nekustamā īpašuma aprakstî̌šana un pārvaldīšana ir vērsta uz īpašuma saglabāšanu tādā stāvoklī, kādā tas ir bijis aprakstes brīdī. Līdz ar to darba algas, kas saistītas ar nekustamā īpašuma uzturēšanu, būtu jāsasaista tieši ar nekustamā īpašuma pārvaldīšanu pēc tā aprakstǐšanas un būtu jānosaka, ka tikai zvērināta tiesu izpildītāja akceptēts nekustamā īpašuma pārvaldnieka norēķins (atskaites par paveiktajiem darbiem un izdevumiem īpašuma uzturēšanā) ir pamats apmaksāt pārvaldnieka darba algu.

\subsection{Hipotēkas noilguma problemātika}

Viens no aktuālākajiem civiltiesību problēmu jautājumiem mūsdienās ir jautājums par hipotēkas noilgumu - vai attiecībā uz hipotēku, kā lietu tiesību, nepastāv noilgums, vai gluži pretēji - hipotēkai ir iespējams noilgums.

Attiecībā uz saistību tiesību noilgumu Civillikuma 1893. pants tiešāa veidā nosaka - saistību tiesības izbeidzas, ja tiesīgā persona tās pienācīgi neizlieto likuma noteiktā noilguma termiṇā.

Jautājumu par hipotēkas noilguma esamību vai neesamību mūsdienu civiltiesībās var risināt ar sistēmiskās iztulkošanas palīdzību. Civillikums neierobežo ķ̄ilas (tajā skaitā hipotēkas) kā blakus tiesības pastāvēšanas terminuu - pēc vispārējā principa ķīlas tiesība ir spēkā, kamēr nav izpildītas saistības, ko ķīla nodrošina. Tas izriet no Civillikuma 1286. panta, kas nosaka, ka ķīlas tiesība paliek spēkā tik ilgi, kamēr pilnīgi apmierināts kreditors, kuram tādēl ķ̄ila atbild pēc daļas samaksas arī par vēl nesamaksāto parāda daļu. Savukārt Civillikuma 1314. pants nosaka, ka ieķ̄̄ātās lietas pārdevums, ko tiesīgi izdarījis ķ̄ilas ņēmējs, izbeidz ne vien viņa paša, bet arī visu viņam sekojošo kreditoru ķ̄ilas tiesības uz šo lietu; bet kā viņam pašam, tā arī pārējiem kreditoriem, kamēr tie nav apmierināti, paliek ķīlas tiesība uz lietas pārdošanā ieņemto summu, ciktāl tā vajadzīga viṇu apmierināšanai. 
Šis princips ir nostiprināts arī Civilprocesa likuma 628. panta otrajā prim dậā: „Ja hipotekārais kreditors nav pievienojies piedziņai (621. panta piektā daļa), nauda zemesgrāmatā norādītās hipotēkas summas apmērā vai hipotekārā kreditora paziṇojumā norādītajā apmērā, ja tāds saņemts (600. panta ceturtā daļa), ņemot vērā attiecīgā hipotekārā prasījuma pirmtiesību, ieskaitāma tā tiesu izpildītāja depozīta kontā, kurš rīkoja izsoli, un uzglabājama līdz izpildu dokumentu saņemšanai." Līdz ar to var secināt, ka attiecībā uz hipotēku civiltiesībās nepastāv noilgums, neskatoties uz to, ka tas nav tiešā tekstā noteikts Civillikumā. Savukārt speciālajā tiesību nozarē - maksātnespējas tiesībās ir ieviests noilgums kreditoru prasījumiem un līdz ar to arī ķīlām, tajā skaitā hipotēkām.

No Maksātnespējas likuma 73. panta pirmās daļas un 141. panta pirmās un pirmās prim dạ̧as izriet, ka kreditoru prasījumi pret parādnieku administratoram ir jāiesniedz mēneša laikā no dienas, kad maksātnespējas reǵistrā izdarīts ieraksts par parādnieka maksātnespējas procesa pasludināšanu. Ja kreditors nokavējis šo termiņu, viņš savu prasījumu pret parādnieku var iesniegt termiņā, kas nav ilgāks par sešiem mēnešiem no dienas, kad maksātnespējas reǵistrā izdarīts ieraksts par parādnieka maksātnespējas procesa pasludināšanu, bet ne vēlāk kā līdz dienai, kad Maksātnespējas likumā noteiktajā kārtībā sastādīts kreditoru prasījumu apmierināšanas plāns (fiziskām personām - sastādīts galīgais bankrota procedūras izmaksu saraksts). Pēc šā termiņa iestājas noilgums, līdz ar to kreditors zaudē kreditora statusu un savas prasījuma tiesības pret parādnieku.

No minētā izriet, ka noilgums attiecas uz visiem kreditoru prasījumiem, kas nav pieteikti administratoram Maksātnespējas likumā noteiktajā termiṇā gan nodrošinātajiem, gan nenodrošinātajiem prasījumiem. Tādējādi Maksātnespējas likumā ietvertās speciālās normas par noilgumu ir attecināmas arī uz publiskajos reǵistros iekḷautajām ķîlām - hipotēkām un komercķīlām. 
Šādu kārtību nevar uzskatīt par civiltiesisko stabilitāti veicinošu, jo kreditoram nepārtraukti ir jāseko līdzi maksātnespējas reǵistra ierakstiem, vai kāds no tā debitoriem nav kḷuvis maksātnespējīgs. Praksē bieži mēdz būt situācijas, ka kreditori nepiesaka savus kreditoru prasījumus parādnieku maksātnespējas procesos, jo vienkārši nav zinājuši par parādnieku maksātnespējas procesa pasludināšanu, piemēram, salīdzinoši nelieli namu apsaimniekošanas un pārvaldīšanas komersanti.

Vienīgais gadījums, kad maksātnespējas administratoram ir jāinformē kreditori, ir nodrošinātie kreditori fiziskas personas maksātnespējas pasludināšanas gadījumā, turklāt arī ar nosacījumiem - pirmkārt, elektroniski, nevis rakstiski pa pastu; otrkārt, tikai tad, ja ir publiski zināma kreditora e-pasta adrese. Tas nav samērīgi ar sekām, kādas iestājas nodrošinātajam kreditoram noilguma iestāšanās un prasījumu zaudēšana gan fiziskās personas maksātnespējas procesa ietvaros, gan pēc saistību dzēšanas procedūras pabeigšanas un parādnieka neizpildīto saistību dzēšanas.

Lai nodrošinātu līdzsvaru starp kreditoram nelabvēlīgām sekām, nepiesakot kreditora prasījumu (prasījuma zaudēšanu), un parādnieka un administratora pienākumiem, būtu jānosaka, ka visos gadījumos administratoram ir jāinformē zināmie kreditori par parādnieka maksātnespējas procesa pasludināšanu. Savukārt noilgums kreditoru prasījumiem varētu iestāties tikai tad, ja kreditors ir bijis informēts, bet nav pieteicis savu kreditora prasījumu maksātnespējas administratoram Maksātnespējas likumā noteiktajos termiņos.

\subsection{Reālnastu arhaisms}

Saskaņā ar Civillikuma 1260. pantu reālnasta ir uz nekustamu īpašumu gul̦ošs pastāvīgs pienākums atkārtoti dot noteiktus izpildījumus naudā, graudā 
vai klaušās. Neskatoties uz to, ka klaušas mūsdienās nepastāv, Civillikumā ir saglabājies šāds regulējums.

Saskaņā ar Civilprocesa likuma 628. panta pirmās daļas 3. punktu zemesgrāmatā ierakstītās reālnastas, kurām pienācis samaksas termiņš, ir sedzamas pirms hipotēkām, kas nostiprinātas uz nekustamo īpašumu. Tas nozīmē, ka reālnastu esamība pasliktina hipotēkas kreditoru stāvokli un to iespējas segt savus prasījumus no ieķīlātā nekustamā īpašuma pārdošanā iegūtās naudas.

Reālnastas ir radušās viduslaiku tiesībās. ${ }^{39}$ Franku valstī 6. gs. beigās kristīgā baznīca prasīja desmito tiesu kā baznīcas nodokli, pamatojoties uz Vecās derības vietām, kas to uzlika ebrejiem. 8. gs. otrajā pusē valsts iestājās par šo baznīcas prasību, lai atlīdzinātu baznīcai par baznīcas zemju sekularizāciju. ${ }^{40}$ Visai Franku valstij, ieskaitot Itāliju, desmitās tiesas nodokli 779. gadā ieviesa Kārlis lielais. Šo nodokli ievāca draudžu mācītāji, bet iegūtos līdzekḷus pēc likuma pārvaldīja bīskapi un sadalīja baznīcas mērķiem saskaņā ar kanoniskām tiesībām. ${ }^{41}$

Tagadējā Latvijas teritorijā desmito tiesu ieveda reizē ar katoḷu ticību. Reizē ar formālu kristietības ievešanu jaunkristītajiem uzlika arī desmito tiesu. Katram, kas kristîjās, līdz ar to tika uzlikts pienākums maksāt katoḷu baznīcai desmito tiesu. 13. gs. sākumā Latvijas teritorijas iedzīvotājiem lauciniekiem uzlika desmito tiesu pilnā apmērā, kā 10\% nodokli no bruto ražas, no lopu pieauguma, no dravas un zvejas ienākumiem. ${ }^{42}$

Šo desmitās tiesas vietā uzlikto nodokli sauca par kunga tiesu jeb gobu. To nenoteica $10 \%$ apmērā no ražas, bet noteiktā pastāvīgā mērā. Desmitā tiesa

${ }^{39}$ Civìltiesības. Sastādīts pēc Latv. Ūniv. jur. fakult. valsts eksāmenu programmas. Rīga: A. Vilka izdevniecība, 1934, 129. 1pp.

40 Sekularizācija (lat. saecularis - pasaulīgs, laicīgs) - Baznīcas īpašuma pārvēršana laicīgā (piemēram, valsts) īpašumā. Sk. Sekularizācija. Iegūts no: http://vesture.eu/index.php/Sekulariz\%C4\%81 cija [sk. 09.06.2016.].

${ }^{41}$ Latvijas tiesību vēsture. [B.V.]: 1944, 188.-189. lpp.

${ }^{42}$ Ibid., 189. lpp. 
bija dievišķo tiesību noteikta, bet kunga tiesa bija tur, kur kāds Dieva kalps aiz žēlastības apžēejojās par jaunkristītajiem un aț̣āva viņiem Dieva tiesas vietā maksāt mazāku nodokli. ${ }^{43}$

Bez desmitās vai kunga tiesas jaunie zemes kungi uzlika Livonijas iedzīvotājiem vēl citas nastas, kam 13. gs. galvenokārt bija militārs raksturs. Pēc 1230. gada līguma kristītiem kuršiem bija jāpiedalās gaitās pret pagāniem ne vien aizstāvēšanās, bet arī uzbrukuma karā, izplatot kristīgo ticību. Tas pats saskaṇā ar līgumiem bija jādara zemgaļiem, igauņiem un citām ciltīm. Turklāt zemes aizsardzības labā nevācu l̦audīm bija jāpiedalās kara klaušās, ceḷot pilis un baznīcas, taisot ceḷus un tiltus. ${ }^{44}$ Reālnastas saglabājās līdz par Vietējo civillikumu kopojuma pieņemšanai 1864. gadā, un to tiesiskais regulējums tika iekḷauts Vietējo civillikumu kopojuma tekstā.

Pēc Latvijas Republikas proklamēšanas notika agrārā reforma, kuras ietvaros normatīvie akti paredzēja reālnastu atcelšanu. Realitātē tas netika izdarīts un 1937. gadā pieṇemtajā Civillikumā reālnastas tika pārṇemtas no Vietējo civillikumu kopojuma.

Reālnastas mūsdienās. Saskaņā ar Valsts vienotās datorizētās zemesgrāmatas statistikas datiem laika periodā no 1998. gada līdz 2017. gada 16. janvārim Latvijā zemesgrāmatās ir iesniegti 329 nostiprinājuma lūgumi reālnastu nostiprināšanai. Laikā no 1993. gada līdz 1997. gadam nav iesniegts neviens nostiprinājuma lūgums. Lielākais skaits nostiprinājuma lūgumu - 267 ir iesniegti Rīgas rajona zemesgrāmatu nodaḷā. ${ }^{45}$

Darba izstrādes ietvaros autors klātienē ir iepazinies ar Rīgas rajona zemesgrāmatu nodaļas informāciju par nostiprinājuma lūgumiem un tiem pievienotajiem dokumentiem par periodu līdz 2016. gada 19. aprīlim, tas ir, par

\footnotetext{
${ }^{43}$ Latvijas tiesību vēsture. [B.V.]: 1944, 190. lpp.

${ }^{44}$ Ibid., 54. lpp.

45 Statistika par darījumiem zemesgrāmatu nodaḷās. Valsts vienotā datorizētā zemesgrāmata. Iegūts no: https://www.zemesgramata.lv/lv/Home/Statistics [sk. 16.01.2017.].
} 
256 reālnastu nostiprinājumu lūgumiem. ${ }^{46}$ No apmierinātajiem nostiprinājuma lūgumiem $87 \%$ ir viena Rīgas rajonā esoša privātmāju ciemata attīstītāja nostiprinājuma lūgumi, bet 16 nostiprinājuma lūgumi 10\% cita Rīgas rajonā esoša privātmāju ciemata attīstītāja nostiprinājuma lūgumi. Tikai $3 \%$ nostiprinājuma lūgumu nav privātmāju ciematu attīstîtāju nostiprinājuma lūgumi.

Abu privātmāju ciematu attīstītāju nostiprinājumu lūgumi ir pamatoti ar līdzīgiem apstākļiem. Attīstītāji pārdod atsevišşus zemesgabalus vai zemesgabalus ar privātmājām un vienlaicīgi ar pirkuma līguma noslēgšanu noslēdz līgumus par koplietošanas cel̦u un infrastruktūras apsaimniekošanu, nostiprinot šos apsaimniekošanas līgumus zemesgrāmatā kā reālnastas. Reālnastu veidā noteikta apsaimniekošanas maksa ir ērta ciematu attīstîtājiem, jo zemesgabalam mainoties īpašniekam, jaunajam ippašniekam ir saistoša zemesgrāmatā ierakstītā reālnasta.

Neskatoties uz to, ka reālnastas ir l̦oti reti izmantots lietu tiesību veids (salīdzinājumā ar 329 reālnastu nostiprinājuma lūgumiem zemesgrāmatu nodaļās kopš 1993. gada ir iesniegts 630899 hipotēkas nostiprinājuma lūgums, ${ }^{47}$ tas ir, 1918 reizes vairāk), reālnastām ir prioritāte pār hipotēkām, ja pret nekustamo īpašumu tiek vērsta piedziņa.

Reālnastas ir izveidojušās feodālisma laikā un Latvijas civiltiesībās spējušas saglabāties līdz mūsdienām, neraugoties uz to, ka to sākotnējais mērķis ir mūsdienām absolūti neatbilstošs. Tā kā reālnastas mūsdienās tiek izmantotas ḷoti reti (turklāt galvenokārt, lai nodrošinātu 2 privātmāju ciematu apsaimniekošanas maksājumu ienākumus no koplietošanas ceḷiem un infrastruktūras), reālnastu institūts būtu modificējams - pirmkārt, būtu jāatsakās

\footnotetext{
46 Šī informācija ir ierobežotas pieejamības informācija un publiski nav pieejama.

47 Statistika par darījumiem zemesgrāmatu nodaḷās. Valsts vienotā datorizētā zemesgrāmata. Iegūts no: https://www.zemesgramata.lv/lv/Home/Statistics [sk. 16.01.2017.].
} 
no klaušām kā reālnastu veida, otrkārt, būtu jāatcel̦ reālnastu prioritāte pār hipotēkām, jo mūsdienās šādai prioritātei nav objektīva pamata.

\subsection{Bezregresa kredītu tiesiskā regulējuma problēmas}

Latvijā laiku pa laikam uzvirmo diskusija par bezregresa hipotekārajiem kredītiem jeb tā saucamo „nolikto atslēgu principu”, paredzot, ka likumos vajadzētu noteikt, ka hipotekārā kredīta ņēmējs (patērētājs) ir atbildīgs par savām saistībām pret kredīta devēju (parasti banku) tikai ieķ̄īātā nekustamā īpašuma vērtības apmērā. Pēc politiķu vārdiem šāds regulējums pastāvot ASV un esot pozitīvi vērtējams.

2015. gada 19. februārī tika pieņemti grozījumi Patērētāju tiesību aizsardzības likumā, papildinot likuma 8. ${ }^{1}$ pantu ar piekto daļu, kas nosaka, ka kredīta devējam pēc kredīta pieprasījuma saņemšanas no patērētāja ir pienākums piedāvāt viṇam izvēlei vismaz divus atšķirīgus kredīta līguma noteikumus, no kuriem viens paredz, ka nekustamais īpašums, kura iegādei tiek ņemts kredīts, kalpo par pietiekamu nodrošinājumu tam, lai saistības pret kredīta devēju varētu tikt dzēstas pilnā apjomā. ${ }^{48}$ Respektīvi, hipotekārajiem aizdevējiem (galvenokārt tās ir bankas) tika uzlikts pienākums, izsniedzot hipotekāro kredītu patērētājiem, piedāvāt patērētājam izvēles iespēju starp regresa un bezregresa kredītu.

Likumprojekta anotācijā ir norādīts, ka likumprojekts nepieciešams, lai pilnībā ieviestu „,nolikto atslēgu principu”, to nesaistot ar maksātnespējas procesu. $^{49}$ Šāds likumprojekta nepieciešamības pamatojums ir ambiciozs. No tā

\footnotetext{
48 Grozījums Patērētāju tiesību aizsardzības likumā: Latvijas Republikas likums. Latvijas Vēstnesis, 42 (5360), 01.03.2015.

${ }^{49}$ Likumprojekta „Grozījums Patērētāju tiesību aizsardzības likumā” sākotnējās ietekmes novērtējuma ziņojums (anotācija). Iegūts no:

http://titania.saeima.lv/LIVS12/SaeimaLIVS12.nsf/0/F091C6D7EEFDE0E1C2257DE30 03E0D86?OpenDocument [sk. 17.10.2016.].
} 
izriet, ka līdz ar grozījumu pieņemšanu Latvijā ir ieviesti bezregresa kredīti, jeb tā saucamais ,nolikto atslēgu princips”.

Bezregresa aizdevums ir aizdevums, kas neietver aizņēmēja personīgu atbild̄̄bu. Aizdevējs ir piekritis, ka nodrošinājums ir pietiekams, un, ja piedziņas gadījumā īpašuma pārdošana dos mazāku summu, nekā aizdevuma summa, aizdevējs cietīs zaudējumus un nevarēs tos piedzīt no aizṇēmēja. ${ }^{50}$

Pastāv argumentēts viedoklis, ka 11 ASV štatos ir bezregresa kredītu sistēma. Štati, kurus var klasificēt kā bezregresa, ir: Aḷaska, Arizona, Kalifornija, Aiova, Minesota, Montāna, Ziemel̦karolīna, Ziemel̦dakota, Oregona, Vašingtona, Viskonsīna. ${ }^{51}$

Lielāko dalıu štatu pret atlikuma piedziņas likumus var iedalīt vienā no šādām kategorijām: 1) tiesību akti, kas aizliedz jebkuru atlikumu atgūšanu pēc īpašuma pārdošanas ne tiesas ceḷā; 2) likumi, kas aizliedz atlikumu piedziņu aizdevumiem, kas nodrošināti ar mājokḷa nekustamo īpašumu; 3) likumi, kas aizliedz atlikumu piedziņu, ja hipotēka nodrošināja īpašuma pirkumam nepieciešamo naudu; 4) likumi, kas ierobežo atlikuma, kas atbilst starpībai starp aizdevuma atlikumu un lielāko no vērtībām - pārdošanas cenu vai ipašuma patieso tirgus vērtību, piedziņu. ${ }^{52}$

Latvijā ar 2015. gada 19. februāra Patērētāju tiesību aizsardzības likuma grozījumiem nav ieviesta bezregresa kredītu sistēma, kāda tā pastāv 11 ASV štatos. Ar grozījumiem ir ieviesta kārtība, ka potenciālajam hipotekārajam kreditoram ir pienākums patērētājam piedāvāt divu veidu kredītus - regresa

\footnotetext{
50 Nonrecourse loan. The Free Dictionary by Farlex. Iegūts no: http://financialdictionary.thefreedictionary.com/nonrecourse+loan [sk. 17.10.2016.].

${ }^{51}$ Ghent A. C., Kudlyaky M. Recourse and Residential Mortgage Default: Evidence from U.S. States. Federal Reserve Bank of Richmond Working Paper No. 09-10R February 25, 2011. Iegūts no: http://ssrn.com/abstract=1432437 [sk. 23.03.2014.].

52 Minnes O., Solomon D. Non-recourse, No Down Payment and the Mortgage Meltdown: Lessons From Undercapitalization. Iegūts no: http://www.law.syr.edu/media/paper/2011/3/Article_SolomonMinnes_March_2011.pdf [sk. 23.03.2014.].
} 
kredītus un bezregresa kredītus. Patērētājam (potenciālajam aizņēmējam) ir tiesības izvēlēties, kuru no kredītiem viņš izmantos. Ja aizņēmējs izvēlas bezregresa kredītu, tad tālākās aizdevēja un aizṇēmēja attiecības attiecībā uz kredīta bezregresa statusu ir pakḷautas pušu līgumiskajām attiecībām, jo nevienā normatīvajā aktā Latvijā nav noteikts bezregresa kredītu tiesiskais regulējums, kā arī aizņēmēja atbildība tikai ieķīātā nekustamā īpašuma apmērā.

Līdz ar to var runāt tikai par līgumiskajiem bezregresa kredītiem Latvijā, turklāt nevis par to, ka tādi ir ieviesti ar 2015. gada 19. februāra grozījumiem Patēētāju tiesību aizsardzības likumā, bet par to, ka ir ieviests pienākums kredīta devējam piedāvāt izvēles iespēju starp regresa un bezregresa kredītiem.

Kredīta devējiem, katru reizi potenciālajam kredīta ņēmējam (patērētājiem) piedāvājot izvēles iespēju starp regresa un bezregresa kredītu, tiek patēēêti resursi - darbinieku laiks, izdales materiāli u.c. Pie zemas bezregresa kredītu izmantošanas (2,3 \% 2015. gadā) ir nelietderīgi saglabāt šādu kredīta devēja pienākumu un tas būtu izslēdzams no Latvijas tiesībām. 


\section{TREŠO PERSONU HIPOTĒKU PROBLĒMU JAUTĀJUMI UN TO RISINĀJUMI}

\subsection{Hipotēkas akcesoritātes problemātika}

Viens no hipotēkas (kā ķīlas tiesību) principiem ir hipotēkas akcesoritātes princips - hipotēkai kā saistības nodrošinājumam ir blakus raksturs. Tas ir, hipotēka var pastāvēt tikai tad, ja pastāv saistība, ko hipotēka nodrošina. Ja saistība nepastāv, tad nevar pastāvēt arī hipotēka, jo hipotēkas mērķis ir nodrošināt saistības izpildīšanu. Neesot saistībai, nepastāv pienākums, kura izpilde būtu jānodrošina.

Par hipotēkas akcesoritātes principu nerastos jautājumi, ja mūsdienās pastāvētu tikai Civillikuma regulējums, kas izriet no Vietējo civillikumu kopojuma. Taču mūsdienās ir arī Maksātnespējas likums, kas attiecībā uz juridiskām personām paredz juridiskas personas likvidēšanu pēc maksātnespējas procesa pabeigšanas, bet attiecībā uz fiziskām personām paredz saistību dzēšanu pēc saistību dzēšanas procedūras pabeigšanas.

Problēmas rodas tajos gadījumos, kad maksātnespējīgā parādnieka saistības nodrošina hipotēka uz trešajai personai piederošu nekustamo īpašumu. Parādnieka maksātnespējas procesa ietvaros saistība tiks izbeigta, visticamāk, nesedzot visu kreditora prasījumu. No tā izriet jautājums - kas notiek ar hipotēku uz trešās personas nekustamo īpašumu? Vai izbeidzot saistību maksātnespējas procesa ietvaros bez tās pilnīga izpildījuma, hipotēka uz trešās personas īpašumu beidz pastāvēt, vai arī turpina pastāvēt kā patstāvīga tiesība?

Hipotēkai par trešās personas saistībām ir zināma līdzība ar galvojumu, jo nodrošinājumu par saistībām dod citas personas (ne parādnieks). Galvojuma gadījumā galvinieks galvo par galvenā parādnieka saistībām. Ja saistības netiek izpildītas, kreditors var prasīt saistību izpildīšanu gan no parādnieka, gan no galvinieka. Hipotēkas par trešās personas saistībām gadījumā kreditors var 
prasīt saistības izpildīšanu no parādnieka, kā arī vērst piedziņu uz ieķīlāto īpašumu. Līdz ar to abos gadījumos kopīgais ir nodrošinājuma došana par trešās personas saistībām, taču galvenā atšķirība ir nodrošinājuma veids. Galvojuma gadījumā nodrošinājums ir personisks - galvinieks personīgi atbild ar visu savu mantu par parādnieka saistībām. Hipotēkas par trešās personas saistībām gadījumā nodrošinājums ir lietisks - tas ir ieķīlātais nekustamais īpašums. Kreditors piedziņu var vērst tikai pret īpašumu, nevis pret tā īpašnieku, turklāt ne vairāk, kā hipotēkas summas apmērā. Ja pēc piedziñas vēršanas uz nekustamo īpašumu izveidojas atlikums, šis atlikums ir atdodams īpašniekam (Civillikuma 1329. pants).

Profesors Vladimirs Bukovskis 1914. gadā ir norādījis, ka ķ̄ilas nodibināšanai par labu citas personas uzṇemtai saistībai ir lietiska galvojuma raksturs, tas ir, tāds galvojums, kas aprobežojas tikai ar ieķīlātās mantas apjomu un nav savienots ar ķîlas devēja personisko atbildību par citas personas parādu. $^{53}$

Gan galvojumam, gan hipotēkai kopīgs ir akcesoritātes princips - šie saistību nodrošinājumi nevar pastāvēt bez saistības. Tāpat galvojumam un hipotēkai kopīgs ir pats svarīgākais, kāpēc šie tiesību institūti vispār pastāv, tas ir, mērķis. Galvojuma un hipotēkas mērķis ir nodrošināties pret saistības neizpildīšanu, tajā skaitā, pret parādnieka maksātnespējas risku.

Līdz ar to atbildi par hipotēkas akcesoritātes principa un hipotēkas kreditora tiesību uz īpašumu kolīzijas atrisināšanu var meklēt Augstākās tiesas Senāta Civillietu departamenta 2011. gada 27. aprīḷa spriedumā lietā Nr. SKC86/2011 un Augstākās tiesas Civillietu departamenta 2016. gada 16. jūnija spriedumā lietā Nr. SKC-178/2016.

53 Буковскій В. Сводъ гражданскихъ узаконеній губерній Прибалтійскихъ съ продолженіемь 1912-1914 2 2. 2. $и$ съ разъясненіями въ 2 томахъ. Томъ I, содержащій Введеніе, Право семейственное, Право вещное и Право насл Бдованія. Рига: Типографія Г. Гемпель и Ко, 1914, стр. 563. 
Senāts savā spriedumā lietā Nr. SKC-86/2011 norādīja uz galvojuma mērķi kā būtiskāko galvojuma spēkā esamības nosacījumu: „Galvojuma akcesoritātes princips nav absolūts, un tādos gadījumos, kad galvojuma kā papildu saistības daba nonāk pretrunā ar galvojuma mērķi, ir piel̦aujami izṇēmumi no tā.

Galvojot par parādnieka saistībām, galvinieks uzn̦emas risku atbildēt kreditoram par parādnieka saistībām arī tad, ja pēdējais nonāktu finansiālās grūtībās. Līdz ar to, galvinieka atbildības pienākums kreditoram par tāda parādnieka, kurš nonācis maksātnespējas situācijā, saistībām tieši atbilst galvojuma mērķim. Turpretī galvinieka atsvabināšana no pienākuma atbildēt kreditoram par galvenā parādnieka saistībām tikai tā iemesla dēḷ, ka parādnieka sliktais finansiālais stāvoklis to novedis līdz maksātnespējai, ir pretrunā ar galvojuma mērḳi.

Minētais ir pamats tam, lai galvojuma mērķim piešķirtu prioritāti pār galvojuma akcesoritāti, kā rezultātā gadījumā, kad galvenais parādnieks komercsabiedrība izbeidzas (tā tiek izslēgta no komercreǵistra, izbeidzot maksātnespējas procesu), galvojums no papildu saistības pārtop par patstāvīgu saistību, vienlaikus arī kreditora prasījums pret galvinieku no galvenajam prasījumam piederīga prasījuma kḷūst par patstāvīgu." ${ }^{24}$

Savukārt savā 2016. gada 16. jūnija spriedumā lietā Nr. SKC-178/2016 Augstākās tiesas Civillietu departaments atrisināja juristu vidū, Saeimas deputātu vidū un tiesību literatūrā vairākus gadus pastāvējušo diskusiju ${ }^{55}$ par galvinieka atbildību, ja maksātnespējas process pasludināts galvenajam

\footnotetext{
${ }^{54}$ Latvijas Republikas Augstākās tiesas Senāta Civillietu departamenta 2011. gada 27. aprīịa spriedums lietā Nr. SKC-86/2011. Iegūts no:

http://at.gov.lv/files/uploads/files/archive/department1/2011/skc-0086.doc [sk. 31.05.2016.].

55 Plašāk sk. Neilands R. Galvojuma patstāvība pēc galvenā parādnieka saistību dzēšanas procedūras pabeigšanas. Jurista Vārds, 16.02.2016., Nr. 7 (910). Iegūts no: http:/www.juristavards.lv/doc/268089-galvojuma-patstaviba-pec-galvena-paradniekasaistibu-dzesanas-proceduras-pabeigsanas/ [sk. 20.07.2016.].
} 
parādniekam - fiziskai personai. Civillietu departaments atzina, ka 2011. gada 27. aprīịa sprieduma lietā Nr. SKC-86/2011 atziņas attiecināmas gan uz gadījumiem, kad galvenais parādnieks ir juridiskā persona, gan uz gadījumiem, kad galvenais parādnieks ir fiziskā persona. ${ }^{56}$

N̦emot vērā to, ka galvojumam un trešo personu hipotēkām galvenās pazīmes ir identiskas (akcesoritāte un mērķis), minētās Civillietu departamenta atziņas ir iespējams attiecināt arī uz trešo personu hipotēkām. Proti, gadījumos, kad parādnieks ir juridiska persona un maksātnespējas procesa rezultātā tā tiek likvidēta (izslēgta no attiecīgā reǵistra), hipotēka no papildus tiesības kḷūst par patstāvīgu tiesību. To pašu var attiecināt uz situāciju, kad parādnieks ir fiziskā persona un tam ir dzēstas saistības, pabeidzot saistību dzēšanas procedūru. Arī šajā gadījumā hipotēka, kas nodibināta, lai nodrošinātu parādnieka saistības, kḷūst par patstāvīgu tiesību, un hipotēkas kreditoram ir tiesības vērst piedziṇu uz ieķīlāto nekustamo īpašumu.

Tiesu praksē ir atrodami piemēri Augstākās tiesas Civillietu departamenta sprieduma lietā Nr. SKC-86/2011 atziņu izmantošanai hipotēku lietās. Piemēram, Rīgas apgabaltiesas Civillietu tiesu kolēgija 2014. gada 30. aprīḷa spriedumā lietā Nr. C27182513, cita starpā, ir atsaukusies uz spriedumu lietā Nr. SKC-86/2011, kā arī norādījusi sekojošo: „Faktiski ķ̄ilas došana par trešās personas saistībām pēc sava tiesiskā rakstura pielīdzināma galvojumam. Abos gadījumos persona ar savu mantu nodrošina kreditora prasījumu pret galveno parādnieku. Ķīlas tiesības gadījumā šāds nodrošinājums aprobežojas vien ar ieķīlāto mantu, bet galvojuma gadījumā - ar visu galvinieka mantu, ja tas nav aprobežots ar noteiktu apmēru. [..]

\footnotetext{
${ }^{56}$ Latvijas Republikas Augstākās tiesas Civillietu departamenta 2016. gada 16. jūnija spriedums lietā Nr. SKC-178/2016. Iegūts no:

at.gov.lv/files/uploads/files/archive/department1/2016/SKC-178-2016.doc [sk. 20.07.2016.].
} 
Tādējādi arī ķ̄ilas devēja atsvabināšana no pienākuma atbildēt kreditoram par galvenā parādnieka saistībām tikai tā iemesla dēḷ, ka parādnieka sliktais finansiālais stāvoklis to novedis līdz ierobežotai maksātspējai, ir pretrunā ar ķīlas mērķi - dot iespēju kreditoram gūt apmierinājumu no ķ̄ilas priekšmeta pārdošanas saistības nesamaksātās daļas apmērā gadījumā, kad kreditors nevar gūt apmierinājumu no paša parādnieka.. ${ }^{, 57}$

Lai problēmas risinājums nebūtu tikai doktrīnas un tiesu prakses ietvaros, būtu nepieciešams veikt grozījumus Civillikumā, papildinot to ar 1306. ${ }^{1}$ pantu šādā redakcijā: „1306. ${ }^{l}$ Koñla par svešu saistību klūst patstāvīga, ja:

1) maksātnespējīgam parādniekam juridiskai personai tiek pabeigts maksātnespējas process un parādnieks tiek izslēgts no attiecīgā registra;

2) maksātnespējīgam parādniekam fiziskai personai pēc saistību dzēšanas plāna izpildes ir dzēstas minētajā plānā norādìtās atlikušās neizpildītās saistības.”

\subsection{Par trešās personas saistībām nodrošinātā kreditora prasījuma īstenošana}

Maksātnespējas likums līdz 2015. gada 1. martam nerisināja jautājumu par to, kā rīkoties situācijā, kad ieķ̄ilātājs ir kḷuvis maksātnespējīgs, bet parādnieks pilda savas saistības. Šajā situācijā nav pamats prasīt ieķīlātās mantas pārdošanu, jo saistība tiek pildīta. Tajā pašā laikā Maksātnespējas likums paredz visas parādnieka mantas pārdošanu un bez tās pārdošanas nevar pabeigt maksātnespējas procesu. Tāpat nav zināms, vai parādnieks savas

\footnotetext{
${ }^{57}$ Rīgas apgabaltiesas Civillietu tiesu kolēgijas 2014. gada 30. aprīḷa spriedums lietā Nr. C27182513. Iegūts no: https://manas.tiesas.lv/eTiesasMvc/nolemumi/pdf/192860.pdf [skatīts 21.09.2016.].
} 
saistības izpildīs pilnībā - ja izpildīs, tad nākotnē nebūs nepieciešams pārdot ķīlas priekšmetu, ja neizpildīs, tad būs nepieciešama tā pārdošana.

Ar Maksātnespējas likuma grozījumiem, kas stājās spēkā 2015. gada 1. martā, ir paredzēts risinājums šādai situācijai. Maksātnespējas likums ir papildināts ar 118. ${ }^{1}$ pantu - Kreditoru prasījumu segšanas kārtība, ja pieteikts tāda nodrošinātā kreditora prasījums, kura prasījuma tiesības atkarīgas no nosacîjuma iestāšanās. Panta būtība ir tāda, ka naudas līdzekḷus no ieḳīạtā īpašuma pārdošanas administrators deponē Maksātnespējas administrācijas speciāli izveidotajā kontā Valsts kasē līdz brīdim, kad nodrošinātais kreditors iesniedzis Maksātnespējas administrācijai paziņojumu par nosacījuma iestāšanos.

Grozījumiem ir viens būtisks trūkums - tie nosaka, ka no ieķīlātā īpašuma pārdošanas saṇemtie naudas līdzekḷi glabājami ne ilgāk kā trīs gadus pēc ieķ̄iātās mantas pārdošanas, vai piecus gadus no parādnieka maksātnespējas procesa pasludināšanas dienas atkarībā no tā, kurš no šiem termiṇiem iestājas ātrāk (118. ${ }^{1}$ panta otrā daļa). Pēc š̄ termiņa līdzekḷi izmaksājami atbilstoši maksātnespējas likuma 118. pantam, tas ir, maksātnespējas procesa izmaksu segšanai, Maksātnespējas administrācijas prasījumu segšanai par parādnieka darbiniekiem izmaksātajām darba algām, nenodrošināto kreditoru prasījumu apmierināšanai pamatparāda apmērā. Šādu kārtību nevar uzskatît par taisnīgu gadījumos, kad saistība, kas nodrošināta ar ķ̄ilu, ir ilgāka par minēto termiņu un turpināsies arī pēc tā. Bieži ir gadījumi, kad saistība ir ilgtermiņa - 5 un vairāk gadi.

Civillikums neierobežo ķīlas (t.sk. hipotēkas) kā blakus tiesības pastāvēšanas terminu - pēc vispārējā principa ķ̄ilas tiesība ir spēkā, kamēr nav izpildītas saistības, ko ķ̄̄la nodrošina. Šis princips ir nostiprināts arī Civilprocesa likuma 628. panta otrajā prim daḷā, saskaņā ar kuru zvērināts tiesu izpildītājs pēc ieķīlāta nekustamā īpašuma pārdošanas, ja hipotekārais kreditors nav pievienojies piedziņai, deponē naudu depozīta kontā zemesgrāmatā 
norādītās hipotēkas summas apmērā vai hipotekārā kreditora paziņojumā norādītajā apmērā, ja tāds saņemts, un uzglabā līdz izpildu dokumentu saņemšanai.

No minētā izriet, ka civilprocesuālajā kārtībā zvērināts tiesu izpildītājs var pārdot ieķîlāto īpašumu, veicot piedziņu (par labu citiem piedzinējiem, ne hipotēkas kreditoram), taču hipotēkas kreditora tiesības netiek aizskartas, jo viṇš jebkurā brīdī tiesu izpildītājam var iesniegt izpildu dokumentu un tādējādi saņemt deponētos līdzekḷus sava prasījuma apmērā.

Līdz ar to ar Maksātnespējas grozījumiem ir izveidota tāda hipotēkas par trešās personas saistībām īstenošanas kārtība, kas ilgtermiņa saistību gadījumos neatbilst taisnīgumam, pārkāpj kreditora tiesības uz īpašumu, kā arī ir pretēja Civilprocesa likumā nostiprinātajai kārtībai un tādējādi pārkāpj kreditoru vienlīdzības principu. Šāda kārtība var radīt jaunas negodprātīgas maksātnespējas shēmas nolūkā gūt mantisku labumu no ieḳīlātā īpašuma pārdošanas, apejot hipotēkas kreditora tiesības. Lai to novērstu, būtu nepieciešami grozījumi Maksātnespējas likuma $118 .{ }^{1}$ pantā, kas atceltu ierobežoto naudas glabāšanas terminu, kam nav jebkāda sakara ar reālo saistības termiņu, un sasaistītu naudas glabāšanu ar saistības pastāvēšanas termiņu. Vien̄̄gais gadījums, kad būtu saglabājams esošais, ierobežotais deponēšanas termiņš, būtu tad, ja kreditoram nav zināms termiņš, kurā nosacījumam jāiestājas (kurā beidzas saistība) vai arī kreditors to nebūtu norādījis savā iesniegumā.

\subsection{Ieķīlātāja tiesības iepaz̄ities ar informāciju par parāda apmēru}

Saistību nodrošināšanas līdzekḷi - hipotēka un galvojums ir civiltiesiski nodrošinājuma līdzekḷi, ko līdzēji var izmantot jebkādu saistību nodrošināšanai. Taču praksē lielākoties šos saistību nodrošinājuma līdzekḷus izmanto 
kredītiestādes (pārsvarā bankas) savos kreditēšanas darījumos, tas ir, izsniedzot kredītus, kas tiek nodrošināti ar galvojumiem un hipotēkām.

Kredītiestādēm saskaņā ar Kredīitiestāžu likuma ${ }^{58}$ 61. panta pirmo daļu ir pienākums garantēt klientu personas, kontu, noguldījumu un darījumu noslēpumu. Šī likuma 62. pantā ir noteikts precīzs to subjektu loks, kam kredītiestādes drīkst izpaust informāciju par klienta darījumiem. Saprotams, ziņas par saviem darījumiem var iegūt pats klients, tajā skaitā aizņēmējs, taču saskaņā ar 62. panta ceturto prim daļu ziņas par klienta kredīta maksājumu grafiku, kredīta saistību izpildi, tajā skaitā veiktajiem maksājumiem un atlikušo parādsaistību apjomu, pēc rakstveida pieprasījuma sniedzamas klienta kredīta galviniekam.

Šāda kārtība tika ieviesta ar 2014. gada 24. aprị̣̄a Kredītiestāžu likuma grozījumiem, kas stājās spēkā 2014. gada 28. maijā, ${ }^{59}$ lai paredzētu galviniekiem tiesības saṇemt informāciju no kredītiestādes par galvoto (aizṇēmēja) kredīta maksājumu grafiku un atmaksas saistību izpildi. ${ }^{60} \mathrm{Ar}$ grozījumiem ievestā kārtība ir vērtējama pozitīvi, jo galviniekiem pirms grozījumiem nebija pamats pieprasīt informāciju no kredītiestādes par parādnieka maksājumu disciplīnu un parāda apmēru. Turklāt kredītiestādēm pat nebija tiesību šādu informāciju izpaust, jo uz šo informāciju attiecās klienta noslēpuma aizsardzība, tajā skaitā pret galviniekiem. Pēc grozījumu pieņemšanas galviniekiem nav šķērṣ̌ı informācijas saņemšanai no kredītiestādēm.

58 Kredītiestāžu likums: Latvijas Republikas likums. Latvijas Vēstnesis, 163 (446), 24.10.1995., Ziņotājs, 23, 07.12.1995.

${ }^{59}$ Grozījumi Kredītiestāžu likumā: Latvijas Republikas likums. Latvijas Vēstnesis, 92 (5152), 14.05.2014.

${ }^{60}$ Likumprojekta „Grozījumi Kredītiestāžu likumā” sākotnējās ietekmes novērtējuma ziņojums (anotācija). Iegūts no:

http://titania.saeima.lv/LIVS11/SaeimaLIVS11.nsf/0/4CB484EDC531C29EC2257C4F0 0417CE5?OpenDocument\#b [sk. 12.10.2016.]. 
Tajā pašā laikā šḳēršlıi informācijas saņemšanai ir saglabājušies attiecībā uz ieķīlātājiem (trešajām personām). Tiem piederošie īpašumi (manta) kalpo kā nodrošinājums kredītiestādes prasījumam, tas ir, tie ir ieķīlāti par labu kredītiestādei, lai nodrošinātu parādnieka saistības. Neskatoties uz to, ieķ̄̄ātājiem nav tiesību pieprasīt informāciju no kredītiestādes par parāda atlikumu un maksājumu disciplīnu. Šāda tiesību neesamība ir uzskatāma par trūkumu, jo ieķ̄̄ạtājiem ir jābūt tiesībām zināt informāciju par saistību atlikumu un maksājumu disciplīnu, jo viņiem piederoši nekustamie īpašumi vai kustamā manta ir ieķīlāti par labu kredītiestādei, lai nodrošinātu parādnieka saistību izpildi. Maksājumu disciplīnas ievērošana un parāda atlikums skar ķīlas devējus, tas ir, viņu tiesības uz īpašumu attiecībā uz ieķîlāto mantu. Ja kredītiestāde uzsāks piedziņu parādnieka saistību nepildī̌sanas dēl, tad piedziņa, visticamāk, tiks vērsta arī pret ieķīlāto mantu, tajā skaitā nekustamo īpašumu. Tādējādi ieķ̄īātājus tiešā veidā ietekmē tas, vai parādnieks pilda saistības, un kāds ir parāda atlikums. Līdz ar to Kredītiestāžu likumā būtu jānosaka, ka arī ieķīlātājam ir tiesības iepazīties ar informāciju par kredīta saistību izpildi un kredīta atlikumu. 


\section{NOBEIGUMS}

Pētîjumā ir pilnībā atbildēts uz pētījuma jautājumiem, atbildes ietverot promocijas darba iztirzājumā, un ir sasniegts promocijas darba mērķis - autors ir sagatavojis zinātnisku pamatojumu hipotēkas institūta stiprināšanai un problēmu jautājumu novēršanai normatīvo aktu grozījumu veidā.

No promocijas darba rezultātiem izriet, ka hipotēkas institūta esošais tiesiskais regulējums Latvijas Republikā ir nepiln̄̄gs, un ir nepieciešami tiesiskā regulējuma uzlabojumi gan Civillikumāa, kā speciālajā hipotēkas institūtu reglamentējošajā normatīvajā aktā, gan citos normatīvajos aktos, kas tiešā veidā skar hipotēkas īstenošanu, jo īpaši Maksātnespējas likumā.

\section{Secinājumi}

Promocijas darbā autors ir izdarījis šādus secinājumus saistībā ar hipotēkas institūtu un tā pilnveidošanas iespējām:

1. Civillikuma pamatā ir Vietējo Civillikumu kopojums, kurš lielākoties sastāvēja no romiešu tiesību normām. Tā kā hipotēkas institūts Civillikumā tika pārṇemts no Vietējo civillikumu kopojuma tikai ar nelieliem redakcionāliem labojumiem, Civillikumā esošais hipotēkas institūts ir balstīts uz hipotēkas institūtu romiešu tiesībās.

2. Hipotēkas mērķis ir identisks visu ķīlu mērķim - prasījuma nodrošināšana tādā veidā, lai kreditors no ķ̄ilas var dabūt prasījuma samaksu.

3. Hipotēka ir visbiežāk izmantotais ķîlu veids. Tas saistīts ar hipotēkas izmantošanu kā vienu no drošākajiem ķīlas veidiem banku kredītu darījumos. Kopš 1993. gada sākuma līdz 2017. gada 16. janvārim zemesgrāmatās ir iesniegti 630899 nostiprinājumu lūgumi hipotēku nodibināšanai. Savukārt otrs plašāk izmantotais ķ1̄lu veids ir komercķ̄ilas - kopš 1998. gada ir registrētas 177175 komercķīlas. Salīdzinot, kopš 
1998. gada ir iesniegti 624769 nostiprinājuma lūgumi hipotēku nostiprināšanai, tas ir, 3,5 reizes vairāk, nekā ir nodibinātas komerck̄īlas.

4. Hipotēkas institūta saturu nosaka ķīlu vispārējie principi - ķīlas akcesoritātes princips, ķīlas nedalāmības princips, ķīlas absolūtuma princips, saistības patstāvības princips, ķīlas atbildības apmēra princips, kā arī speciālie hipotēkas principi - hipotēkas pirmtiesības princips, zemesgrāmatu publiskās ticamības princips un hipotēkas specializācijas princips.

5. Hipotēkas nostiprināšanas zemesgrāmatā sekas ir: 1) lietu tiesību rašanās; 2) nostiprināto tiesību neapstrīdamība; 3) saistošais raksturs visiem; 4) pirmtiesības rašanās; 6) kreditora tiesības uzsākt bezstrīdus piespiedu izpildīšanu saistību neizpildes gadījumā; 7) kreditora tiesības pārdot ķīlas priekšmetu labprātīgā izsolē par brīvu cenu, ja šāda tiesība pielīgta hipotēkas līgumā; 8) kreditora aizsardzība, ja pret ieḳīāto īpašumu tiek vērsti citi prasījumi; 9) nodrošinātā kreditora statuss parādnieka (ieķ̄īātāja) maksātnespējas procesā, tiesiskās aizsardzības procesā vai ārpustiesas tiesiskās aizsardz̄̄bas procesā.

6. Mainoties izīrētā mājokḷa īpašniekam, îres līgums paliek spēkā un ir saistošs jaunajam īpašniekam. Nolūkā kavēt piedziņas procesu, novilcināt laiku jaunā īpašnieka ievešanai nosolītā īpašuma valdījumā, kaitēt hipotēkas kreditoram, kā arī nodrošināt sev un saviem radiniekiem iespēju pēc iespējas ilgāk dzīvot ieķ̄̄lātajā dzīvoklī vai dzīvojamā mājāa, par to nemaksājot ne kredīta maksājumus, ne reālus īres maksājumus, negodprātīgi parādnieki mēdz noslēgt fiktīvus īres līgumus ar saviem radiniekiem, svaiņiem, draugiem vai paziṇām. Šādi fiktīvi īres līgumi ir saistoši jaunajam īpašniekam, kas dzīvokli vai dzīvojamo māju ir nopircis zvērināta tiesu izpildītāja rīkotajā izsolē.

7. Bez fiktīviem īres līgumiem cits veids kā tiek aizskartas hipotēkas kreditora likumīgās intereses, ir fiktīvu darba līgumu noslēgšana par 
ieķīātā nekustamā īpašuma uzturēšanu un tiesas sprieduma iegūšana par darba algas piedziņu. Atbilstoši Civilprocesa likuma 628. panta pirmās daḷas 1. punktam no ieķīạtā nekustamā īpašuma pārdošanas ienākumiem ar hipotēkām nodrošinātie prasījumi tiek segti tikai ceturtajā kārtā (pēc darba algām saistībā ar ieķīlātā īpašuma uzturēšanu, ar īpašumu saistītajiem nodokḷiem un reālnastām, kurām pienācis samaksas termiņš). Šo normu izmantojot, fiktīvie darbinieki iegūst izpildu dokumentus par darba algas piedziņu un tos iesniedz zvērinātam tiesu izpildītājam, nolūkā saṇemt ienākumus no pārdotā ieḳīlātā nekustamā īpašuma pirms hipotēkas kreditora, tas ir, saņemt hipotēkas kreditoram pienākošos naudu.

8. Sistēmiski iztulkojot Civillikuma 1286. pantu, 1314. pantu un Civilprocesa likuma 628. panta pirmo daļu var secināt, ka attiecībā uz hipotēku civiltiesībās nepastāv noilgums. Savukārt speciālajā tiesību nozarē - maksātnespējas tiesībās ir ieviests noilgums kreditoru prasījumiem un līdz ar to arī ķ̄ilām, tajā skaitā hipotēkām.

9. Vienīgais gadījums, kad maksātnespējas administratoram ir jāinformēe kreditori par parādnieka maksātnespējas pasludināšanu, ir nodrošinātie kreditori fiziskas personas maksātnespējas pasludināšanas gadījumā, turklāt arī ar nosacījumiem - pirmkārt, elektroniski, nevis rakstiski pa pastu; otrkārt, tikai tad, ja ir publiski zināma kreditora e-pasta adrese. Tas nav samērīgi ar sekām, kādas iestājas nodrošinātajam kreditoram noilguma iestāšanās un prasījumu zaudēšana gan fiziskās personas maksātnespējas procesa ietvaros, gan pēc saistību dzēšanas procedūras pabeigšanas un parādnieka neizpildīto saistību dzēšanas.

10. Reālnastas ir arhaisks feodālo tiesību institūts, kura mērķis vēsturiski bija nodrošināt feodāḷu un baznīcas ienākumus desmitās tiesas, kunga tiesas un klaušu veidā. Mūsdienās reālnastas tiek izmantotas ļoti reti, turklāt neatbilstoši to mērķim - atsevišķu privātmāju ciematu attīstītāju 
apsaimniekošanas maksas iekasēšanai par ciematu koplietošanas cel̦iem, teritorijām un infrastruktūru.

11. ASV tikai vienpadsmit štatos pastāv bezregresa kredīti, pretēji Latvijā valdošajam uzskatam, ka šādi kredīti pastāv visos ASV štatos. Lielākā daļa bezregresa kredītu likumu mūsdienās pastāv kā vēsturiskas pēdas parādu atvieglojumiem, kuri tika pieņemti 1930. gados - ASV Lielās depresijas ietekmē.

12. Latvijā bezregresa kredīti pastāv tikai līgumiskā veidā - par tiem vienojoties kredīta līgumā ar patērētāju. 2016. gada 9. jūnijā tika pieņemti grozījumi Patērētāju tiesību aizsardzības likuma $8 .{ }^{1}$ pantā, ar kuriem noteikts, ka kredīta devējam, kas saņēmis no patērētāja kredīta pieprasījumu, ir pienākums piedāvāt viņam izvēlei vismaz divus atšķirīgus patērētāja kreditēšanas līguma noteikumus, no kuriem viens paredz, ka nekustamais īpašums, kura iegādei tiek ņemts kredīts, kalpo par pietiekamu nodrošinājumu tam, lai saistības pret kredīta devēju varētu dzēst pilnā apjomā. Ar šo normu, neskatoties uz politiķu apgalvojumiem, Latvijā nav ieviesti bezregresa kredīti. Ir noteikts nesamērīgs administratīvais slogs kredīta izsniedzējiem, neskatoties uz to, ka bezregresa kredītus kredītñēmēji izvēlas l̦oti reti (2015. gadā tikai 2,3\% no visiem izsniegtajiem kredītiem mājsaimniecībām).

13. Hipotēkas akcesoritātes principa ietvaros rodas problēmas tajos gadījumos, kad maksātnespējīgā parādnieka saistības nodrošina hipotēka uz trešajai personai piederošu nekustamo īpašumu. Parādnieka maksātnespējas procesa ietvaros saistība tiks izbeigta, visticamāk, nesedzot visu kreditora prasījumu. Ja š̄i iemesla dēḷ akcesoritātes principa ietvaros beigtu pastāvēt arī hipotēka, tas nonāktu pretrunā ar hipotēkas kreditora tiesībām uz īpašumu. N̦emot vērā tiesu praksi un judikatūru, var izdarīt secinājumu, ka hipotēkas mērķis prevalē pār tās akcesoritātes principu. Dzēšot parādnieka (fiziskas personas) saistības pēc saistību 
dzēšanas procedūras pabeigšanas vai, likvidējot juridisku personu maksātnespējas rezultātā, hipotēka kḷūst patstāvīga, un hipotēkas kreditoram ir tiesība vērst savu atlikušo prasījumu uz ieķīlāto nekustamo īpašumu, kas pieder trešajai personai.

14. Gan no tiesu prakses, kas izveidojās pirms Maksātnespējas likuma 2014. gada 25. septembrī pieņemtajiem grozījumiem, gan pēc šiem grozījumiem no Maksātnespējas likuma 7. panta izriet, ka gadījumos, kad maksātnespējīgā parādnieka manta ir ieķīlāta par trešās personas saistībām, kreditora statuss šì maksātnespējīgā parādnieka maksātnespējas procesā (arī TAP un ĀTAP) ir nodrošinātais kreditors. Savukārt gadījumos, kad maksātnespējīgā parādnieka saistības nodrošina ķ̄ila uz citas personas mantu, ķ̄ilas kreditora status maksātnespējīgā parādnieka maksātnespējas procesā (ar̄̄ TAP un ĀTAP) ir nenodrošinātais kreditors, un šādā gadījumā maksātnespējas procesa administratoram nav tiesības atsavināt trešajai personai piederošo un par parādnieka saistībām ieķīlāto mantu, tajā skaitā nekustamo īpašumu.

15. Maksātnespējas likuma 118. ${ }^{1}$ pantā ir ietverta tāda hipotēkas par trešās personas saistībām īstenošanas kārtība, kas ilgtermiņa saistību gadījumos neatbilst taisnīgumam, pārkāpj kreditora tiesības uz īpašumu, kā ar̄̄ ir pretēja Civilprocesa likumā nostiprinātajai kārtībai un tādējādi pārkāpj kreditoru vienlīdzības principu. Šāda kārtība var radīt negodprātīgas maksātnespējas shēmas nolūkā gūt mantisku labumu no ieķīlātā īpašuma pārdošanas, apejot hipotēkas kreditora tiesības.

16. Saskaņā ar Kredītiestāžu likuma 62. panta ceturto prim daļu ziņas par klienta kredīta maksājumu grafiku, kredīta saistību izpildi, tajā skaitā veiktajiem maksājumiem un atlikušo parādsaistību apjomu, pēc rakstveida pieprasījuma sniedzamas klienta kredīta galviniekam. Šķēešsļi informācijas saņemšanai pastāv attiecībā uz ieķīlātājiem (trešajām personām). Tiem piederošie īpašumi (manta) kalpo kā nodrošinājums kredītiestādes 
prasījumam, tas ir, tie ir ieķīlāti par labu kredītiestādei, lai nodrošinātu parādnieka saistības. Neskatoties uz to, ieķīātājiem nav tiesību pieprasīt informāciju no kredītiestādes par parāda atlikumu un maksājumu disciplīnu. Šāda tiesību neesamība ir uzskatāma par trūkumu, jo ieķ̄̄ātājiem ir jābūt tiesībām zināt informāciju par saistību atlikumu un maksājumu disciplīnu, jo saistību nepildīšanas gadījumā piedziņa tiks vērsta uz viniiem piederošo un par labu kredītiestādei ieķīlāto mantu.

\section{Priekšlikumi}

Ar hipotēkas institūtu saistīto problēmu atrisināšanai autors izvirza šādus priekšlikumus normatīvo aktu grozījumiem:

1. Fiktīvo īres līgumu problēmas atrisināšanai ir nepieciešams noteikt, ka tikai zemesgrāmatās ierakstītie īres līgumi ir saistoši jaunajam īpašniekam. Šobrīd izstrādes procesā ir Dzīvojamo telpu īres likums, kurā šis princips ir paredzēts (27.pantā), taču nav paredzēts, ka zemesgrāmatā ierakstīt īres līgumu var tikai ar hipotēkas kreditora piekrišanu, ja īpašums ir apgrūtināts ar hipotēku. Līdz ar to Dzīvojamo telpu īres likumprojekta 27. pants būtu jāpapildina ar trešo daḷu šādā redakcijā:

„(3) Ja nekustamais ìpašums vai dzīvojamā telpa ir apgrūtināts ar hipotēku, tad ìres līgumu zemesgrāmatā var ierakstīt tikai ar hipotēkas kreditora rakstisku piekrišanu."

2. Fiktīvo darba līgumu problēmas atrisināšanai Civilprocesa likuma 628. panta pirmās dal̦as 1. punkts būtu jāizsaka jaunā redakcijā:

\section{„628.pants. Ar ķ̄ilu apgrūtināta nekustamā īpašuma pārdošanā saṇemtās naudas sadalīšana}

(1) No naudas, kas saņemta par pārdoto ar ķ1̄lu apgrūtinātu nekustamo īpašumu, vispirms sedzami sprieduma izpildes izdevumi, kas saistīti ar 
nekustamā īpašuma pārdošanu, pēc tam apmierināmi prasījumi šādā secībā:

1) nekustamā īpašuma pārvaldnieka prasījums par darba algas, kas saskaņota ar tiesu izpildītāju, samaksu, tajā skaitā ar pārvaldnieka darba algu saistītie sociālās apdrošināšanas maksājumi. Šajā punktā noteiktais prasījums attiecināms tikai uz periodu no nekustamā īpašuma aprakstīšanas dienas līdz nekustamā īpašuma nodošanas dienai jaunajam ipašniekam."

3. Lai novērstu kreditoru tiesību aizskārumu, iestājoties noilgumam parādnieku maksātnespējas procesos, Maksātnespējas likuma 73. pantu un 141. pantu būtu jāpapildina ar šādām dạ̦ām:

\section{„73.pants. Kreditoru prasījumu iesniegšana}

$\left(1^{1}\right)$ Administrators nekavējoties nosūta paziņojumu par maksātnespējas procesa pasludināšanu visiem zināmajiem parādnieka kreditoriem.

$\left(2^{l}\right) \quad J a$ administrators kreditoram nav nosūtījis pazinojumu par maksātnespējas procesa pasludināšanu, š̄ panta otrajā daḷā noteiktās sekas neiestājas.

\section{1.pants. Kreditoru prasijumi un kreditoru sapulce}

$\left(2^{2}\right) \quad J a$ administrators kreditoram nav nosūtījis paziņojumu par maksātnespējas procesa pasludināšanu, š̄ panta pirmajā prim daļā noteiktās sekas neiestājas."

4. Nolūkā stiprināt hipotēkas institūtu, kā arī risināt reālnastu arhaisma problēmu, būtu nepieciešams no Civilprocesa likuma 628. panta pirmās daļas izslēgt trešo punktu (reālnastu prioritāti pār hipotēkām), kā arī no Civillikuma 1260. panta izslēgt vārdu "klaušās" un no Civillikuma 1276. panta izslēgt vārdus "vai klaušās”.

5. Nolūkā mazināt administratīvo slogu un nelietderīgu resursu patēriņu kredītu devējiem, no Patērētāju tiesību aizsardzības likuma 8. ${ }^{1}$ panta būtu nepieciešams izslēgt astoto daļu, kas nosaka kredīta devēja pienākumu 
piedāvāt potenciālajam kredīta ņēmējam izvēlei vismaz divus atšķirīgus patērētāja kreditēšanas līguma noteikumus, no kuriem viens paredz, ka nekustamais īpašums, kura iegādei tiek ņemts kredīts, kalpo par pietiekamu nodrošinājumu tam, lai saistības pret kredīta devēju varētu dzēst pilnā apjomā. Izslēdzot šādu normu no Patērētāju tiesību aizsardzības likuma, kredīta devējam un kredīta ņēmējam tāpat kā līdz normas pieņemšanai būtu iespēja kredīta līgumā savstarpēji vienoties par bezregresa kredīta noteikumiem.

6. Lai hipotēkas akcesoritātes problēmas risinājums nebūtu meklējams tikai doktrīnas un tiesu prakses ietvaros, būtu nepieciešams veikt grozījumus Civillikumā, papildinot to ar 1306. ${ }^{1}$ pantu šādā redakcijā:

„1306. ${ }^{l}$ Ķ̄lla par svešu saistību kḷūst patstāvīga, ja:

1) maksātnespējīgam parādniekam juridiskai personai tiek pabeigts maksātnespējas process un parādnieks tiek izslēgts no attiecīgā registra;

2) maksātnespējīgam parādniekam fiziskai personai pēc saistību dzēěsanas plāna izpildes ir dzēstas minētajā plānā norādītās atlikušās neizpildītās saistības."

7. Lai novērstu Maksātnespējas likuma 118. ${ }^{1}$ pantā ietvertās hipotēkas par trešās personas saistībām īstenošanas kārtības neatbilstību taisnīgumam, kreditoru tiesību uz īpašumu aizskārumu, un kreditoru vienlīizīības principa pārkāpumu, būtu nepieciešami grozījumi Maksātnespējas likuma 118. ${ }^{1}$ pantā, kas atceltu ierobežoto naudas glabāšanas terminu, kam nav jebkāda sakara ar reālo saistības termiņu, un sasaistītu naudas glabāšanu ar saistības pastāvēšanas termiņu. Vienīgais gadījums, kad būtu saglabājams esošais, ierobežotais deponēšanas termiņš, būtu tad, ja kreditoram nav zināms termiṇš, kurā nosacījumam jāiestājas (kurā beidzas saistība), vai arī kreditors to nebūtu norādījis savā iesniegumā. N̦emot vērā minēto, Maksātnespējas likuma 118. ${ }^{1}$ panta otrā daḷa būtu jāizsaka šādā redakcijā: 


\section{„118. ${ }^{1}$ pants. Kreditoru prasījumu segšanas kārtība, ja pieteikts tāda nodrošinātā kreditora prasījums, kura prasījuma tiesības atkarīgas no nosacījuma iestāšanās}

[..]

(2) Šā panta pirmajā daḷā minêtie naudas lìdzekļi glabājami ne ilgāk kāa lìdz nodrošinātā kreditora iesniegumā norādītajam datumam, lìdz kuram nosacījumam jāiestājas.

Ja nav zināms datums, lìdz kuram nosacījumam jāiestājas, šā panta pirmajā daḷa minētie naudas lìdzekļi glabājami ne ilgāk kā trīs gadus pēc tam, kad ieķīlātā manta ir pārdota par labu nodrošinātajam kreditoram, kura prasījuma tiesības atkarīgas no nosacījuma iestāšanās, vai piecus gadus no parādnieka maksātnespējas procesa pasludināšanas dienas atkarībā no tā, kurš no šiem termiņiem iestājas agrāk."

8. Ieķīlātājus tiešā veidā skar tas, vai parādnieks pilda saistības, un kāds ir parāda atlikums. Kredītiestāžu likumā būtu jānosaka, ka ne tikai galviniekam, bet arī ieķīātājam ir tiesības iepazīties ar informāciju par kredīta saistību izpildi un kredīta atlikumu. N̦emot vērā minēto, Kredītiestāžu likuma 61. panta ceturtajā prim dạ̦a būtu jāizsaka šādā redakcijā:

\section{„62.pants.}

(4 $\left.{ }^{l}\right)$ Ziņas par klienta kredīta maksājumu grafiku, kredīta saistību izpildi, tajā skaitā veiktajiem maksājumiem un atlikušo parādsaist̄̄bu apjomu, pēc rakstveida pieprasījuma sniedzamas klienta kredīta galviniekam un ieķīātājam, kuram piederoša manta ieķīlāta klienta kredīta nodrošināšanai." 


\section{Izmantotās literatūras un avotu saraksts}

1. Bukovskis V. Civīlprocesa mācības grāmata. Rīga: Autora izdevums, 1933.

2. Civìltiesības. Sastādīts pēc Latv. Ūniv. jur. fakult. valsts eksāmenu programmas. Rīga: A. Vilka izdevniecība, 1934.

3. Čakste K. Civiltiesības. Lekcijas. Raksti. Rīga: Zvaigzne ABC, 2011.

4. Finanšu stabilitātes pārskats 2016. Latvijas Banka. Iegūts no: https://www.makroekonomika.lv/sites/default/files/fsp_2016_1.pdf [sk. 07.11.2016.].

5. Gailīte D. Frīdrihs Georgs fon Bunge. Jurista Vārds, 11.11.2014., Nr. 44/45 (846/847).

6. Grīns A. (red.). Pasaules vēsture. I daļa. Senie laiki. Rīga: Grāmatu draugs, 1929.

7. Harris R. Recourse and Non-recourse Mortgages: Foreclosure, Bankruptcy, Policy. Iegūts no: http://ssrn.com/abstract=1591524 [sk. 23.03.2014.].

8. Jackson T.C. Justian's Digest (Book 20) with an English Translation and an Essay on the Law of Mortgage in the Roman Law. London: Sweet and Maxwell, Limited, 1908. Reproduction: Lavergne: Gale, 2014.

9. Kalniņš E. Ievads grāmatai: Vīnzarājs N. Civiltiesību problēmas. Raksti (1932.1939.). Rīga: Erlena Kalniņa un Viktora Tihonova izdevums, 2000.

10. Kalniņš V. Romiešu civiltiesību pamati. 1977. gadā publicētās grāmatas faksimilizdevums. Rīga: Apgāds Zvaigzne ABC, 2010.

11. Kalniņš V. Romiešu ķīlu tiesību attīstība. Jurists, 01.03.1939., Nr. 3/4 (97/98).

12. Kalniņš V. Romiešu tiesību nozìme mūsu laikos. Novilkums. Jurists, 1939., Nr. 7/8(101/102).

13. Komercḳīlu registrācijas dinamika. Lursoft statistika. Iegūts no: https://www.lursoft.lv/lursoft_statistika/?\&id=63 [sk. 16.01.2017.].

14. Latvijas tiesību vēsture. [B.V.]: 1944.

15. Lazdinš J., Osipova S. Latvijas un Eiropas viduslaiku tiesību vēsturē sastopamie jēdzieni un to skaidrojumi. Rīga: LU tipogrāfija, 1996.

16. Lēbers A. Civiltiesības un civilprocess: kara juridiskos kursos lasīto lekciju konspekts. Rīga: 1921.

17. Likumprojekta „Grozījumi Kredītiestāžu likumā” sākotnējās ietekmes novērtējuma ziņojums (anotācija). Iegūts no:

http://titania.saeima.lv/LIVS11/SaeimaLIVS11.nsf/0/4CB484EDC531C29EC2257 C4F00417CE5?OpenDocument\#b [sk. 12.10.2016.].

18. Likumprojekta „Grozījums Patērētāju tiesību aizsardzības likumā” sākotnējās ietekmes novērtējuma ziņojums (anotācija). Iegūts no:

http://titania.saeima.lv/LIVS12/SaeimaLIVS12.nsf/0/F091C6D7EEFDE0E1C225

7DE3003E0D86?OpenDocument [sk. 17.10.2016.].

19. Minnes O., Solomon D. Non-recourse, No Down Payment and the Mortgage Meltdown: Lessons From Undercapitalization. Iegūts no:

http://www.law.syr.edu/media/paper/2011/3/Article_SolomonMinnes_March_201 1.pdf [sk. 23.03.2014.].

20. Neilands R. Galvojuma patstāvība pēc galvenā parādnieka saistību dzēšanas procedūras pabeigšanas. Jurista Vārds, 16.02.2016., Nr. 7 (910). Iegūts no: http://www.juristavards.lv/doc/268089-galvojuma-patstaviba-pec-galvenaparadnieka-saistibu-dzesanas-proceduras-pabeigsanas/ [sk. 20.07.2016.]. 
21. Nonrecourse loan. The Free Dictionary by Farlex. Iegūts no: http://financialdictionary.thefreedictionary.com/nonrecourse+loan [sk. 17.10.2016.].

22. Rozenfelds J. Lietu tiesības. 4. labotais, papildinātais izdevumus. Rīga: Zvaigzne ABC, 2011.

23. Sekularizācija. Iegūts no: http://vesture.eu/index.php/Sekulariz\%C4\%81cija [sk. 09.06.2016.].

24. Sinaiskis V. Latvijas civiltiesību apskats. Lietu tiesības. Rīga: L.U. Studentu padomes grāmatnīcas izdevums, 1940.

25. Sinaiskis V. Latvijas civiltiesību apskats. Lietu tiesības. Saistību tiesības. Rīga: Latvijas juristu biedrība, 1995.

26. Statistika par darījumiem zemesgrāmatu nodaļās. Valsts vienotā datorizētā zemesgrāmata. Iegūts no: https://www.zemesgramata.lv/lv/Home/Statistics [sk. 16.01.2017.].

27. Švābe A. Jaunais Civīllikums latvju tiesību vēstures gaismāa. No: Prezidenta Ulmaņa Civīllikums. Rakstu krājums. Rīga: Pagalms, 1938.

28. Буковскій В. Сводъ гражданскихъ узаконеній губерній Прибалтійскихъ съ продолженіемъ 1912-1914 2 2. г. и съ разъясненіями въ 2 томахъ. Томъ I, содержащиій Введеніе, Право семейственное, Право вещное и Право насльдованія. Рига: Типографія Г. Гемпель и Ко.

29. Краснокутский В. А. МБстное гражданское право губерній прибалтійскихъ и привислянскихъ. Пособіе къ лекиіямъ. Москва: Типографія Императорскаго Московскаго Университета, 1910.

30. Пахман С. В. Исторія кодификаціи гражданскаго права въ двухъ томахъ. Томъ II. С.-Петербургъ, 1876.

31. Покровский И.А. История римского права. [Romiešu tiesību vēsture]. Iegūts no: http://civil.consultant.ru/elib/books/25/page_42.html [sk. 17.03.2016.].

\section{Normatīvie akti:}

32. Grozījums Patērētāju tiesību aizsardzības likumā: Latvijas Republikas likums. Latvijas Vēstnesis, 42 (5360), 01.03.2015.

33. Grozījumi Maksātnespējas likumā: Latvijas Republikas likums. Latvijas Vēstnesis, 204 (5264), 15.10.2014.

34. Grozījumi Kredītiestāžu likumā: Latvijas Republikas likums. Latvijas Vēstnesis, 92 (5152), 14.05.2014.

35. Maksātnespējas likums: Latvijas Republikas likums. Latvijas Vēstnesis, 124 (4316), 06.08.2010.

36. Kredītiestāžu likums: Latvijas Republikas likums. Latvijas Vēstnesis, 163 (446), 24.10.1995., Ziņotājs, 23, 07.12.1995.

37. Likums „Par atjaunotā Latvijas Republikas 1937. gada Civillikuma ǵimenes tiesību daḷas spēkā stāšanās laiku un kārtību": Latvijas Republikas likums. Latvijas Vēstnesis, 35, 08.06.1993., Ziņotājs, 22/23, 10.06.1993.

38. Zemesgrāmatu likums: Latvijas Republikas likums. Ziņotājs. 16, 29.04.1993., Likumu un noteikumu krātuve. 38, 30.12.1937.

39. Likums „Par atjaunotā Latvijas Republikas 1937. gada Civillikuma saistību tiesību daļas spēkā stāšanās laiku un kārtību": Latvijas Republikas likums. Ziņotājs. 1/2, 14.01.1993. 
40. Likums „Par atjaunotā Latvijas Republikas 1937. gada Civillikuma ievada, mantojuma tiesību un lietu tiesību daḷas spēkā stāšanās laiku un kārtību": Latvijas Republikas likums. Ziņotājs. 29/31, 30.07.1992.

41. Latvijas Republikas likums Civillikums. Valdības Vēstnesis, 41, 20.02.1937.

\section{Tiesu prakse:}

42. Latvijas Republikas Augstākās tiesas Civillietu departamenta 2016. gada 16. jūnija spriedums lietā Nr. SKC-178/2016. Iegūts no:

at.gov.lv/files/uploads/files/archive/department1/2016/SKC-178-2016.doc

[sk. 20.07.2016.].

43. Latvijas Republikas Augstākās tiesas Senāta Civillietu departamenta 2011. gada 27. aprīla spriedums lietā Nr. SKC-86/2011. Iegūts no:

http://at.gov.lv/files/uploads/files/archive/department1/2011/skc-0086.doc [sk. 31.05.2016.].

44. Rīgas apgabaltiesas Civillietu tiesu kolēgijas 2014. gada 30. aprīḷa spriedums lietā Nr. C27182513. Iegūts no:

https://manas.tiesas.lv/eTiesasMvc/nolemumi/pdf/192860.pdf [sk. 21.09.2016.]. 